\title{
Bagratashen 1, a stratified open-air Middle Paleolithic site in the Debed river valley of northeastern Armenia: a preliminary report
}

\author{
Charles P. Egeland ${ }^{1} *$ \\ Boris Gasparian ${ }^{2}$ \\ Cynthia M. Fadem ${ }^{3}$ \\ Samvel Nahapetyan ${ }^{4}$ \\ Dmitri Arakelyan ${ }^{5}$ \\ Christopher M. Nicholson ${ }^{6}$
}

1. Department of Anthropology, University of North Carolina at Greensboro

2. Institute of Archaeology and Ethnography, National Academy of Sciences of the Republic of Armenia

3. Department of Geology, Earlham College

4. Department of Cartography and Geomorphology, Yerevan State University

5. Institute of Geological Sciences, National Academy of Sciences of the Republic of Armenia

6. Water Resources Data System, Department of Civil and Architectural Engineering, and Department of Anthropology, University of Wyoming, USA

* Correspondence to: Charles P. Egeland, Department of Anthropology, University of North Carolina at Greensboro, 426 Graham Building, Greensboro, North Carolina, 27402, USA;

Phone: (336) 256-8547; Fax: (336) 334-5674; E-mail: cpegelan@uncg.edu 


\begin{abstract}
The southern Caucasus is home to a particularly rich record of Middle Paleolithic (MP) occupation. However, the potential contribution of the southern Caucasus to broader discussions of MP behavior and adaptations has remained largely unfulfilled because many key archaeological assemblages, deriving as they do from either surface scatters or sites that were excavated without the benefit of modern archaeological techniques, lack critical contextual information. What is more, the relatively small sample of sites where such data are available has been heavily biased towards caves and rockshelters. Here, we present a preliminary report on Bagratashen 1, an open-air MP site stratified within an ancient terrace of the Debed River in northeastern Armenia. While no faunal material has yet been recovered, site formation analysis suggests that the lithic assemblage, although subjected to subaerial exposure and some degree of post-depositional alteration, is neither severely biased nor substantially reworked. The presence of numerous cores and primary flaking debris indicate that at least some reduction occurred onsite. It appears that a majority of the raw material was probably procured locally from the nearby river channel, although a handful of obsidian pieces reveal raw material movements on the order of $80 \mathrm{~km}$. The Bagratashen 1 lithic assemblage also includes several elongated points that recall early MP artifacts from the Levant and other sites in the southern Caucasus that date to between 250 and 90ka BP. Optically Stimulated Luminescence samples from within the find horizon, however, returned dates of $\sim 34 \mathrm{ka} \mathrm{BP}$. While a terminal MP date requires confirmation, Bagratashen 1 provides an interesting case with which to test the utility of formal lithic artifacts as chrono-cultural markers.
\end{abstract}




\subsection{Introduction}

The set of cultural phenomena referred to collectively as the Middle Paleolithic (MP) endured for some 200,000 years and stretched from Europe to the Near East and into the western reaches of Asia. Studies of these extraordinarily successful adaptations, when viewed in light of the succeeding Upper Paleolithic (UP), have yielded valuable insights into both continuities and breaks between archaic and (presumably) modern human populations in terms of subsistence (Adler et al., 2006; Grayson and Delpech, 2003; Henry et al., 2014; Münzel and Conard, 2004), technology (Eren et al., 2008; Marks et al., 2001), and social dynamics (Gamble, 1999). The diversity long known to exist within the MP, especially when assessed on its own terms and without direct reference to UP accomplishments, has also revealed that these societies were not only sophisticated and flexible but varied a good deal across both space and time (Bar-Yosef and Kuhn, 1999; d'Errico, 2003; Delagnes and Meignen, 2006; Delagnes and Rendu, 2011; Gaudzinski-Windheuser and Roebroeks, 2011; Marks and Chabai, 2006; Meignen et al., 2006; Stiner and Kuhn, 1992). In fact, the development of regionally specific material cultures, evidenced most conspicuously in methods of lithic procurement, production, and utilization, is one of the hallmarks of the MP (Kuhn, 2013).

While decades of high quality research has documented these cultures in some detail, a consensus on the causes of spatio-temporal variability and/or stasis within and among them, be it regionally bounded social traditions, functional/strategic responses, demographic factors, or cultural drift/convergence, remains elusive (Hovers and Belfer-Cohen, 2006; Kozłowski, 2014; Kuhn, 2012, 2013; Mellars, 1996: 342-355; Ruebens, 2013). Such uncertainty is perhaps inevitable given the vagaries of the archaeological record, complexity of the behaviors involved, and unevenness with which various regions have been sampled. It is almost certainly correct, for 
example, that the datasets and attendant behavioral reconstructions from Europe and the Levant, while currently unmatched in their detail, do not necessarily apply in other settings (cf. Kuhn and Hovers, 2006: 4; Mellars, 1996: 5-6). The ability of researchers to systematically link the responses of MP groups to fluctuations in local socio-ecological conditions in site- and data-rich areas like southern France (Daujeard et al., 2012; Delagnes and Rendu, 2011), southwestern Germany (Conard et al., 2012), the Levant (Hovers and Belfer-Cohen, 2013; Shea, 2008), and elsewhere nevertheless highlights the need for and utility of long-term, multidisciplinary research programs that generate fine-grained datasets from multiple sites within circumscribed geographies.

The southern Caucasus (Figure 1), defined here as the modern republics of Armenia, Azerbaijan, and Georgia, has much to offer in this context given its diverse landscapes (Gulisahvili et al., 1975; Krever et al., 2001; Volodicheva, 2002) and numerous MP occurrences (Adler and Tushabramishvili, 2004; Golovanova and Doronichev, 2003; Liubin, 1989). Yet until very recently southern Caucasian data have factored only peripherally in broader discussions of MP lifeways, a situation due, at least in part, to geopolitics and Western scholars' unfamiliarity with local research (much of which is published in Russian). Foremost, however, is the fact that a vast majority of the area's sites are surface scatters or were excavated without the benefit of modern archaeological techniques. Like their counterparts in much of Europe, Soviet-era scholars, relying chiefly on data from the Georgian Republic's rich collection of caves and rockshelters, sought to identify clusters of lithic assemblages with shared tool categories (based largely on Bordian typologies), techniques of blank production, and faunal associations. These sets were thought to reflect ethnic groups with distinct settlement-subsistence systems (Liubin, 1977; Nioradze, 1992; Tushabramishvili, 1984). The dearth of reliable chronometric dates 
hindered a precise temporal arrangement of the assemblages, so it was surmised that various MP groups may have occupied the region more-or-less contemporaneously (see discussion in Adler, 2002: 8-13; Adler and Tushabramishvili, 2004: 94-95).

Later syntheses, while acknowledging variation within and between lithic collections, condense the Caucasian record into three groupings (Doronichev, 1993; Golovanova and Doronichev, 2003). The first, represented by sites on the northern slopes of the Greater Caucasus, corresponds techno-typologically to the East European Micoquien, particularly in the presence of small bifaces. The second includes sites on the southern slopes of the Greater Caucasus, particularly in Georgian Abkhazia, Imeretia, and South Ossetia, which are densely packed with caves and rockshelters. This area, which Golovanova and Doronichev (2003: 81) describe as a "composite cultural area" that, because it samples a variety of flaking methods (e.g., Levallois vs. non-Levallois), blank products (e.g., laminar vs. non-laminar), and specific tool types (e.g., elongated retouched points), is thought to comprise "a number of different local cultural entities," some of which recall MP technologies from the Taurus and Levant (see also Pleurdeau et al., 2007). The last, and southernmost, encompasses the Armenian (Javakhetian) Highlands and Lesser Caucasus of Armenia, southern Georgia, and western Azerbaijan. The industries that make up this group are said to resemble those of the Zagros. Many researchers thus conclude that northern Caucasian MP groups were more closely related culturally to eastern Europe while those from the southern Caucasus were heavily influenced by the Levant and Taurus/Zagros (Beliaeva and Liubin, 1998; Doronichev and Golovanova, 2003; Golovanova and Doronichev, 2003; Liubin, 1989).

These schemes, while all credible attempts to organize what is admittedly a complex record, are based on decades-old excavations, many of which did not systematically screen 
sediments and lacked fine stratigraphic control and reliable chronometric dates. What is more, the primarily descriptive nature of these frameworks is ultimately unsatisfying in light of efforts to evaluate MP lithic and subsistence economies in strategic, cost/benefit terms guided by principles of behavioral ecology (Adler et al., 2006; Dusseldorp, 2012; Kuhn, 1995; Kuhn and Stiner, 2006). While it is reasonable to expect that similarities in technology (the production and use of which is, after all, a socially learned behavior) reflect cultural connectedness, it is also unclear how, or if, the presence/absence or frequencies of particular tool forms, general similarities in reduction techniques, or patterned faunal associations truly reflect such relationships rather than, say, convergence or local development from the preceding Acheulean (Adler et al., 2014; Mercier et al., 2010: 168; Tushabramishvili et al., 2007).

As is the case for the southern Caucasus as a whole, the MP is Armenia's most wellrepresented and intensively studied Paleolithic phenomenon (Gasparyan et al., 2014). Using surface finds collected around Mt. Arteni and in the Hrazdan Gorge, M. Z. Panichkina (1950) and S. H. Sardarian (1954) were the first to systematically distinguish and organize the county's MP record. Both researchers found the Armenian assemblages a better match for those from the Mediterranean Basin and western Asia than to the classic Mousterian of western Europe. It was not until the discovery of the caves of Yerevan 1 and Lusakert 1 in the late 1960s, however, and their periodic excavation and analysis over many years under the direction of B. G. Yeritsyan (1970, 1971, 1972a, c, 1976, 1979; Yeritsyan and Korobkov, 1979), that any hint of an in situ, stratified MP occupation was established. In 1973, Yerevan 1 produced what were identified as the parietal and deciduous molar of a Neanderthal child (Bader et al., 1976: 24; Gasparyan et al., 2014: 75; Yeritsyan and Khudaverdyan, 2013: 22), and both sites eventually yielded thousands of lithics and faunal remains. Yeritsyan originally assigned the lower units (Units 5, Z, 6, and 7) 
of Yerevan 1 and the middle unit (Unit D) of Lusakert 1, together with several open-air sites along the Hrazdan Gorge and in the vicinity of Mt. Arteni, to Armenia's oldest MP manifestation. However, all of these lithic assemblages are now recognized as examples of terminal MP technologies (Adler et al., 2009, 2012; Fourloubey et al., 2003; Gasparyan et al., 2014; Golovanova and Doronichev, 2003). The stone tool collections from both Yerevan 1 and Lusakert 1 exhibit various forms of truncation-faceting, with one of the most characteristic features being the presence of small, triangular points with truncated-faceted bases from Units 13 at Yerevan 1 (Yeritsyan, 1972b). These pieces are distinct enough to have merited the term "Yerevan points" and are found at several other sites in the region (Golovanova and Doronichev, 2003; Liagre et al., 2006; Yeritsyan, 1970, 1971, 1972b).

Although Yerevan 1 and Lusakert 1 are well-known and, thus, among the few Armenian MP sites even mentioned in regional and pan-regional syntheses (Beliaeva and Liubin, 1998; Cohen and Stepanchuk, 1999; Doronichev and Golovanova, 2003; Golovanova and Doronichev, 2003, 2005; Kozlowski, 1998; Lioubine and Beliaeva, 2006; Liubin, 1989), they remain plagued by dating inconsistencies and were, until recently, the only stratified, in situ MP sites in all of Armenia. Therefore, and despite a long tradition of Paleolithic research in the southern Caucasus, and Armenia in particular, those interested in characterizing MP settlement are equipped with only a handful of sites that (1) preserve stratified deposits; (2) have been excavated with modern archaeological techniques; and (3) are associated with reliable chronometric dates. Progress has been further hindered by a notable bias towards caves and rockshelters. As detailed below, this situation is improving rapidly, and here we present preliminary data from Bagratashen 1, a stratified, open-air MP site within the Debed river valley of northern Armenia.

\subsection{Geographic, environmental, and geological context}


Situated between the Black and Caspian Seas, the southern Caucasus is a topographically diverse region of lofty mountains, deep valleys, wide basins, and numerous rivers. This rugged landscape was formed by a combination of continental uplift, volcanic activity, river incision, and glacial movements over the past 20 million years or so (Volodicheva, 2002). Modern Armenia is dominated by the Lesser Caucasus and Armenian Highlands, whose 400 to $600 \mathrm{~mm}$ of yearly precipitation currently supports shrubby steppic vegetation. This flora appears to have persisted through entire glacial-interglacial cycles, which suggests that a relatively dry continental climate endured in the region throughout the Pleistocene (Joannin et al., 2010).

Bagratashen 1 (41.23N, 44.82E, 457masl) is located within the valley of the Debed River, which passes through the northern ranges of the Lesser Caucasus and eventually discharges into the Kura lowlands of modern Georgia and Azerbaijan. The downcutting of the Debed has exposed a thick Quaternary sequence that contains abundant Paleolithic materials. Bagratashen 1 was discovered in August of 2009 during a reconnaissance survey of the Debed valley and its tributaries (Egeland et al., 2010, 2014) (Figure 2). Lithic material, including a well-made handaxe, eroding from a recently built road cut was the first indication of the site's existence, and a small $20 \times 10 \times 5 \mathrm{~cm}$ step excavated into the slope confirmed the presence of an in situ archaeological horizon two meters below the modern (i.e., pre-road construction) ground surface.

The archaeological material is situated within an ancient terrace of the Debed River. The package of sediments is consistent throughout, with the deposition of fine-grained, quartz-rich material interrupted only by periods of stability and the formation of at least four paleosols. Xray diffraction reveals mineralogically similar parent materials for these soils; crystalline quartz and calcite appear throughout the profile and gypsum and/or brushite is common in several of the B horizons. The indurated B horizons are pedogenic accumulations that, while differing in their 
degree of formation, are indistinguishable chemically. The artifacts of the main find layer reside partly in the B horizon of the third paleosol (Figure 3).

The consistency of the deposit in both detrital and pedogenic chemistry suggests a typical Quaternary formation scenario whereby aeolian and fluvial processes deposited quartz-rich silt at rates variable enough to permit the formation of soils. As the episodes of deposition do not vary substantially in source material characteristics, it is likely that only the rate of the site's longterm sediment dynamics varied throughout the time of its accumulation. This is advantageous from a geoarchaeological standpoint, as any depositional changes must therefore be related to variation in the availability of source material (e.g., episodic presence of volcanic ash) or transport energy (e.g., wind and water velocity), and pedogenic development should reflect the duration of surface stability and local climate regimes. While many of these analyses are ongoing, we can infer that the heavily indurated B horizons at Bagratahsen 1 formed in relatively long-lived soils. The third B horizon, which partially encases the MP artifact layer, forms a discontinuous cemented horizon and is thus the most well-developed of these pedogenic accumulations. At least a portion of the Bagratashen 1 artifact matrix would therefore have directly underlain a long-lived surface.

\subsection{Materials and methods}

\subsubsection{Excavation protocol}

In 2010, a 5 x 3 m trench (hereafter Trench 1) was placed to encompass the densest concentration of artifacts exposed in 2009 and to assess the integrity of the deposit (this was later expanded to $6 \times 3 \mathrm{~m}$ ). Excavations initiated from the modern ground surface determined that the upper layers contain a low density scatter of Modern/Medieval (Archaeological Horizon 1) and Chalcolithic/Upper Paleolithic (Archaeological Horizon 2) material. Once the floor of Trench 1 
neared the edge of the road cut, a $3 \times 2 \mathrm{~m}$ step was created and, upon reaching the main archaeological horizon, systematic excavations commenced by square meter (in 2010) or quarter square (in 2011) in arbitrary 5-10 cm levels (Figure 4). The MP component was divided into two Archaeological Horizons: 3a contained a handful of scattered artifacts while $3 \mathrm{~b}$ contained a dense and vertically discrete $(\mathrm{ca} .50 \mathrm{~cm})$ concentration of lithic material. To date, all archaeological material from within Archaeological Horizon $3 b$ has been removed from a total area of just over $6 \mathrm{~m}^{2}$ in Trench 1. Excavations have not yet proceeded below this MP horizon.

Two additional trenches, Trenches 2 and 3, were placed $10 \mathrm{~m}$ and $35 \mathrm{~m}$, respectively, northwest of Trench 1 in 2011 (Figure 5). Trench 2, which measured 5 x 3 m, extended nearly 4 $\mathrm{m}$ below the modern ground surface and produced a handful of isolated MP artifacts but no evidence for a continuation of the main occupation identified in Trench 1 (Figure 6). Trench 3 measured $2 \times 2 \mathrm{~m}$ and was excavated to just over a meter below the modern ground surface and yielded no artifacts. The archaeological deposit nevertheless continues into the slope of the road cut in Trench 1, and additional MP material was observed eroding from the graded surface to the southeast. So, although the spatial extent of the site, which was certainly truncated by the road construction, is unknown, it likely encompasses at least many tens of square meters.

All material $>2 \mathrm{~cm}$ in maximum dimension recovered in situ was piece-plotted in three dimensions with a laser total station. For those pieces with a clear long (or "A") axis, two points were recorded, one each at the base of the piece at either end along the midline, which permitted the calculation of trend and plunge (McPherron, 2005). Artifact class (lithic, sediment sample, dating sample) and side up (e.g., dorsal or ventral for lithic pieces) were also recorded. For the 2010 field season, sediments were dry-screened through $1 \mathrm{~mm}$ mesh, while in 2011 water screening through nested $3 \mathrm{~mm}, 1 \mathrm{~mm}$, and $0.25 \mathrm{~mm}$ mesh was employed. 


\subsubsection{Optically stimulated luminescence dating}

Five samples from within the main artifact-bearing horizon were taken for optically stimulated luminescence (OSL) dating (see Figure 4). Sediments were collected by hammering opaque plastic tubes into the profile face. The open ends of the tubes were covered with electrical tape immediately after their extraction. Cosmic dose rates were estimated from Prescott and Hutton (1994) based on the burial depth of the samples and site altitude, latitude, and longitude.

\subsubsection{Lithic analysis}

Between 2009 and 2011, a total of 568 lithic pieces were recovered from the surface and as in situ finds within the trenches. Unfortunately, the currently excavated portion of the MP horizon is devoid of faunal material (although bone may have at one time been present; see below). Thus, behavioral reconstructions are necessarily based only on the site's lithic assemblage, and the analyses that follow focus on the 500 artifacts, regardless of size, that were excavated in situ from within Archaeological Layer 3b in Trench 1. This sample includes all dryscreened material from 2010 but excludes the 2011 water-screened material, which has yet to be curated. The following scheme is employed to organize the Bagratashen 1 assemblage:

- Flakes. These are pieces with clear ventral and dorsal faces, ripples marks, and, when the proximal end is present, platforms, bulbs of percussion, and/or eraillure scars. Five categories of flake are recognized. Points, or pointed flakes, are roughly triangular in shape and possess two sharp edges that converge to form a tip. Blades are defined as flakes more than twice as long as they are wide with parallel lateral edges. Although both points and blades can be created with either Levallois (or "prepared") or non-Levallois 
(e.g., laminar blade production) techniques, we differentiate them from Levallois flakes, which are non-point and non-blade pieces with well-organized dorsal scar patterns and whose form appears to have been predetermined through intentional core preparation. Platform truncation flakes are small pieces that result from the deliberate removal of a flake's proximal end. These flakes typically retain the original flake's platform and can possess two bulbs of percussion, one from the truncated flake and the other from the impact of the truncation itself. The final category, unspecified, includes any flake or flake fragment that is not a point, blade, Levallois flake, or platform truncation flake. Any of these artifact types may preserve evidence of secondary modifications including truncation, truncation-faceting, and/or retouch. Here, truncations include the removal of one or both ends of a flake with abrupt retouch and/or a single blow.

- Cores. These artifacts show unambiguous negative scars from which potentially useful flakes have been removed. While a variety of classification systems exist, our preliminary analysis follows that of Conard et al. (2004), which, because it is largely descriptive, is easy to implement, readily reproducible, and does not impose any meaning onto variation in core morphology. Four categories are present in the Bagratashen 1 assemblage. The first, Initial cores, show only a few removals and preserve much of the piece's original volume. This category includes tested pieces, choppers, and those hammerstones from which flakes were accidently detached. The second, Parallel cores, have two surfaces that run more-or-less parallel to each other and the plane that intersects them. These cores possess "a slightly convex main removal surface and a more inclined "underside"” (Conard et al. 2004: 14-15). This category encompasses Levallois cores and their variants in which flaking is "organized along the flattened surface of the [core], with a series of 
removals more or less parallel to this plane" (Meignen, 1998: 172-173). Parallel cores are further distinguished based on the directionality of major flake removals (unidirectional, bidirectional, multidirectional). The third category is Inclined cores, which retain two flaking surfaces that are inclined relative to the plane that intersects them. Inclined cores tend to be conical or biconical (that is, most removals converge at the center of the flaking surface or surfaces) and may be either centripetally (i.e., worked around the entire, or nearly the entire, perimeter; "discoid" cores are included here) or noncentripetally worked. Regardless, most removals are angled at roughly $45^{\circ}$ relative to the plane of intersection. The final category, Irregular cores, includes exhausted cores, core fragments, and cores that cannot be easily grouped as an Initial, Parallel, or Inclined core.

- Manuports. These are stones that were transported on-site by humans but show no unambiguous evidence of having been knapped. Complete or split cobbles/pebbles and pieces with battering (possible hammerstones or anvils) are included in this category.

- Core elements. These materials result from core preparation (e.g., decortification flakes, shaping debris) and/or maintenance (e.g., débordants, éclats outrepassé, platform rejuvenation), although they may not necessarily possess the features of flakes. Core elements can also appear in other categories (e.g., a retouched débordant is also considered a secondarily modified flake).

- Indeterminate. Artifacts in this final category do not fall securely into any category and comprise pieces referred to variously in other studies as angular waste, debris, or chunks.

The metric attributes recorded for each specimen are shown in Table 1. The categorization of platform types follows Inizan et al. (1999: 134, 136) and Monigal (2002: 150), and raw material 
identifications are based on macroscopic attributes. The Bagratashen 1 artifacts display a number of post-depositional modifications, including (1) a carbonate encrustation, or cutan, which occurs on the ventral and/or dorsal face; (2) weathering/patina, which we employ in a very broad sense to reflect any sort of discoloration via chemical and/or mechanical weathering of original knapped surfaces; (3) polish, or the extent to which a surface, usually smoothened to some degree, reflects incident light; and (4) rounding, or the smoothness of the ridges of edges and flake scars. Using a customized version of Thompson's (2009) system, the severity of each attribute was scored on an ordinal scale (Table 2). Those artifacts bearing carbonate cutans were cleaned in a diluted acid solution after scoring.

\subsection{Results}

\subsubsection{Dating}

Two of the five collected samples were analyzed at the Luminescence Dating Research Laboratory (Department of Earth and Environmental Sciences, University of Illinois-Chicago) and returned ages of $30.5 \mathrm{ka}$ and $37.9 \mathrm{ka} \mathrm{BP}_{\mathrm{OSL}}$. Table 3 provides details on the age estimates.

\subsubsection{Artifact preservation and site integrity}

Table 4 summarizes the frequency occurrence and severity of post-depositional modifications in the Bagratashen 1 assemblage. Carbonate encrustation (285 out of 500; 57\%) and patina (346 out of 500;69\%) are both fairly common. Of those pieces that could be confidently scored for carbonate severity, about $93 \%$ are either lightly covered or covered to such an extent as to completely obscure the artifact's features. Likewise, just over $95 \%$ of the scored pieces are heavily patinated and, and such, preserve no trace of the original (that is, freshly knapped) surface. Rounding and polish, on the other hand, occur only very rarely. 
Overall, most pieces are well preserved and show sharp edges despite exposure to postdepositional physico-chemical processes.

In arid regions, pedogenic carbonate is thought to derive largely from the dissolution of carbonate from calcareous dust (Gile et al., 1966). As they precipitate out of soils, carbonate cutans typically form first on the bottom of larger clasts. Over time, they can accumulate to cover the entire clast as they fill pore spaces (Treadwell-Steitz and McFadden, 2000). Thus, if the archaeological horizon at Bagratashen 1 experienced significant post-depositional movement, one might anticipate a high frequency of coatings oriented randomly relative to the artifacts' position in the sediment. Table 5 demonstrates that of the 230 pieces for which a clear side-up aspect could be recorded, only $15 \%$ show a crust on the top only, while a majority $(\sim 76 \%)$ have coatings on either both sides or on the underside only.

The relative frequency of lithic particle sizes is shown in Figure 7. All stages of reduction are represented at Bagratashen 1 (see below) so if little or no post-depositional disturbance occurred, a distribution of particle sizes similar to experiments that sample complete knapping sequences is expected. The archaeological assemblage shows a clear deficiency of pieces $<2 \mathrm{~cm}$, which suggests some level of disturbance, probably the result of fluvial processes. The stereographic projection and rose diagram of those pieces with clear A-axes, however, indicate an isotropic fabric (Figure 8), and statistical analysis confirms that artifact orientations do not differ significantly from a uniform distribution (Table 6). It seems, then, that hydraulic flow did not orient materials preferentially. Recall, too, that the water screened material has yet to be analyzed, so while some bias is likely, its magnitude has yet to be fully explored. Ad hoc refitting produced four conjoined sets (each of two pieces) separated horizontally by a minimum of 7.1 
$\mathrm{cm}$ and a maximum of $88.6 \mathrm{~cm}$ and vertically by a minimum of $0.1 \mathrm{~cm}$ and a maximum of 16.7 cm (Figure 9).

As mentioned above, no faunal material has yet been recovered from the artifact horizon. While this could be due to sampling bias or a true absence from the original assemblage, we note that calcite is present throughout the deposit and that the x-ray diffraction spectra of the B horizon chemical precipitates, including that from the third paleosol encasing the artifacts, are consistent with both calcium phosphate (brushite) and calcium sulfate (gypsum). Groundwater is the likely input for the sulfate, as it occurs only in the lower third of the profile. Pedogenic accumulations are nevertheless present in each of the B horizons, even in the upper parts of the profile that lack sulfate. This inconsistency favors brushite for at least some of the pedogenic accumulations. If this is borne out by further analysis, and because bone mineral is lowcrystallinity carbonated hydroxyapatite (a calcium phosphate), it is possible that dissolved bone was the source for the brushite in these deposits.

\subsubsection{Raw material exploitation}

Macroscopic examination reveals three main raw materials represented in the flaked (i.e., non-manuport) component of the Bagratashen 1 collection (Figure 10): obsidian, chert, and a

fine-grained, gray-to-black lava that we preliminarily identify as dacite. Other fine-grained lavas, sandstone, tuff, and limestone are represented by a handful of flaked pieces, including an elongated retouched point made from the latter. Obsidian is represented by small unretouched flakes or chips only. Unretouched flakes also make up the majority of the chert pieces, though a biface fragment, a side scraper, an elongated retouched point, and a core trimming element were also flaked from this raw material. This contrasts markedly with the pattern seen for dacite, which is represented by all stages of reduction, from initial core preparation and rejuvenation to 
finished products. Those dacite cores that are large enough to distinguish their original form likely represent cobbles, and it is possible that they were collected from the nearby river where they are common today.

\subsubsection{Lithic industry}

Table 7 summarizes the typological composition of the Bagratashen 1 collection. While a detailed exploration of the site's lithic economy must await the recovery of additional material and a full morpho-technological analysis, the sample now available does reveal several features worthy of note. The first is the prevalence of cores $(n=38)$, which make up nearly $8 \%$ of the assemblage. They are all flaked from dacite and consist, in order of descending frequency, of parallel cores (47.4\% of the core sample), irregular cores (26.3\% of the core sample) and, in equal frequency, initial and inclined cores (each 13.2\% of the core sample). Unidirectional and bidirectional methods were employed by MP knappers to reduce parallel cores, while a majority of the inclined cores were non-centripetally flaked (Figure 11). The parallel cores can be considered "Levallois" in the sense that all were obviously prepared for the removal of flakes with pre-determined shapes. Second, truncation and truncation-faceting are relatively common methods of blank modification. This is evidenced not only by the presence of these modifications but by the high frequency of platform truncation flakes. This all strongly suggests that truncation was intentional rather than the result of post-depositional fragmentation or production breaks.

Finally, the assemblage contains a handful of distinctive elongated points, or pointed blades, many of which are retouched. Superficially similar end products such as these can arise from an array of reduction systems, and it appears that those from Bagratashen 1 were produced via at least two distinct knapping strategies. The first, likely represented in its earlier stages by the assemblage's parallel cores, generated dorso-ventrally thin, pointed blades with faceted 
platforms and multiple dorsal flake scars (Figure 12). Typologically, these pieces can be classified as elongated variants of Levallois or retouched Levallois/Mousterian points. The second resulted in pointed blades that are thicker dorso-ventrally with faceted and non-faceted platforms, triangular or trapezoidal cross-sections, and stepped lateral retouch (Figure 13). Meignen (1998) suggests that the production of these particular blanks requires narrow, highly convex surfaces, which is a feature that parallel cores, with their flat and wide active faces, do not provide. Elongated flakes resulting from this reduction technique, referred to as "series blades" by Copeland (1983: 17) and "prismatic blades" by Jelinek (1982: 75), are typically detached from one or more well-defined striking platforms, and the continuous (rather than after successive preparation) and contiguous removals around the core's lateral edges can give rise to semi-pyramidal or semi-prismatic forms ("platform cores" in the terminology of Conard et al., 2004). No identifiable cores that correspond to this so-called "Laminar system" (Meignen, 1994) occur in the excavated assemblage, although one such artifact was recovered from the surface (Egeland et al., 2014: 378). A variety of shorter points exist in the collection as well, and they too can be classified typologically as Levallois or retouched Levallois points.

There has been much discussion on the possible use of stone points as hafted elements for weapons. The tip cross-sectional area (TCSA) and perimeter (TCSP) of such pieces in particular have been shown to readily distinguish different classes of weaponry and, importantly, whether archaeological artifacts of unknown function could plausibly have been used as part of projectile armatures and/or thrusting spears (Hughes, 1998; Shea, 2006; Sisk and Shea, 2009, 2011). Relevant quantitative and qualitative attributes for all the Bagratashen 1 points are presented in Table 8. Taken as a whole, the point sample from Bagratashen 1 shows a TCSA mean that is higher than that of ethnographic arrow and dart points and very similar to that from points hafted 
onto experimental thrusting spears. The Bagratashen 1 TCSP sample mean is also higher than that of the ethnographic projectile samples but lower than that of the experimental thrusting spear tips (Figure 14).

Despite the presence of elongated points, the assemblage as a whole does not exhibit a great deal of laminarity. Table 9 summarizes the metrics for the site's complete blanks (in this case flakes, blades, and points $>25 \mathrm{~mm}$ in maximum length without secondary modification such as retouch or truncation) and shows that the mean length:width ratio is only 1.67 . The mean length:width ratio of the non-broken Levallois points $(\mathrm{n}=14)$ is 1.99 , although many of these pieces $(n=9)$ have been artificially shortened via truncation and/or basal thinning. The laminar index is 24.1 when complete blanks only are considered and rises to 29.0 with the inclusion of the complete (i.e., unbroken and not truncated) retouched points. A handful of other retouched pieces exist in the assemblage and include side scrapers, notches, and a single endscraper made on a débordant (Figure 15). The most common platform types, in order of descending frequency, are plain, faceted, and truncated, although cortical platforms are not rare (Figure 16). Nearly half (46.4\%) of the complete blanks preserve some dorsal cortex, which, coupled with the prevalence of cores, suggest that at least some production occurred on-site.

\subsection{Discussion}

\subsubsection{Bagratashen 1 and the MP in the southern Caucasus}

The number of chronometrically dated MP assemblages in the southern Caucasus has increased greatly in the last decade or so, but a substantial bias towards caves and rockshelters is still apparent (Table 10). Older conventional radiocarbon dates (e.g., Kudaro I, Yerevan 1) are now viewed with suspicion, although more recently published samples result in anomalously recent and/or stratigraphically incoherent data (e.g., Kalavan 2, Bronze Cave), which shows that 
even ages generated with advanced pre-treatment techniques can suffer from imprecise provenience (particularly from older excavations), contamination, and/or post-depositional movement (Adler et al., 2008: 831; Ghukasyan et al., 2011: 48). The currently available data nonetheless suggest that in the southern Caucasus the MP sensu stricto began around 260kya and persisted until perhaps $37 \mathrm{kya}^{1}$. The OSL data from Bagratashen 1 thus fall at the very end of the MP range in the region. We readily acknowledge that, like any other estimate based on a single technique, this date should be treated cautiously, particularly since (1) it is based on a multiplegrain analysis susceptible to signal averaging and (2) gamma dose rates were not measured in situ. As we detail below, however, there are good reasons to seriously consider a late MP date for the Bagratashen 1 occupation.

It is very unlikely that the spatial pattering and artifact representation at Bagratashen 1 are "pristine" in any true sense of the word, as very well preserved open-air sites, even those in favorable depositional contexts like floodplains, have probably been modified to some extent by geomorphological processes (e.g., Sitzia et al., 2012). The thickness of the MP horizon, when combined with the evidence for extended sub-aerial exposure, also suggest that the Bagratashen 1 assemblage likely represents a palimpsest of various activities spread out over a potentially long period of time rather than a behavioral snapshot. We do note, however, that the occurrence of pedogenic mineral accumulations in the same sequence across both Trench 1 and Trench 2 demonstrates the long-term integrity of the Bagratashen 1 deposits in toto. The coincidence in the main find horizon of these heavy precipitates with a dense collection of lithics suggests either (1) the artifacts themselves provided enhanced porosity that encouraged precipitation out of

\footnotetext{
${ }^{1}$ The synchronous production of bifacial and Levallois technology at the late Acheulean site of Nor Geghi 1 (Armenia) shows that in the southern Caucasus at least some Middle Paleolithic technologies have deep roots in the preceding Lower Paleolithic (Adler et al., 2014). The earliest MP assemblages in the region will thus not necessarily be populated solely by flake-based "Middle Paleolithic" products, a situation that complicates attempts to identify a temporal point of origin for this phenomenon.
} 
groundwater solution, or (2) the precipitates replaced the minerals of once-present bones. The totality of the data nevertheless indicates that the lithic assemblage, although subjected to subaerial exposure and some degree of post-depositional alteration, is neither severely biased nor substantially reworked. Further excavations, a concerted refitting effort, and additional sedimentological and soil analyses should help clarify this issue.

The presence of a handful of obsidian artifacts is noteworthy given that this toolstone would not have been locally available. The nearest known sources are the Chikiani dome in southern Georgia, the Aparan group in the Tasghkunyats Range of central Armenia, and the Sizavet and Aghvorik sources in northwestern Armenia, all of which are situated at least 80 linear km from Bagratashen 1 (Badalyan et al., 2004; Le Bourdonnec et al., 2012; Chataigner and Gratuze, 2014; Doronicheva and Shackley, 2014; Frahm et al., 2014). The near exclusive use of dacite as a raw material suggests that it was relatively easy to obtain and well suited to the tasks at hand. Very little is known about the distribution of non-obsidian raw materials in northern Armenia, although it is likely that the Debed and its tributaries served as important secondary sources of dacite and other rock types. Limestone and flint of Cretaceous age can be found just north and east of the site on the southern fringes of the Papakar Range. While ease of access therefore probably played a key role in raw material selection at Bagratashen 1, the durability afforded by fine-grained volcanics like dacite relative to more brittle rocks like obsidian may also have been a factor (Egeland et al., 2014: 382).

When examined individually, only two of the Bagratashen 1 points could have conceivably been used as projectile armatures, with the remainder possibly having functioned effectively as tips for thrusting spears. However, only one of the excavated points exhibits a broken tip, and we stress, as have others (e.g., Sisk and Shea, 2009: 2046), that in the absence of 
ancillary data (e.g., use wear, impact fractures), metric analysis indicates only the plausibility, and not the certitude, of point function.

As we note elsewhere (Egeland et al., 2014: 376), the Bagratashen 1 elongated retouched points bear some resemblance to artifacts recovered from MP contexts in the Levant, among them Layer F and Lower E from Hayonim Cave (Meignen, 1998, 2011), the Upper Terrace (Units I, II, III, and 3, 4, 5, 6) at Misliya Cave (Zaidner and Weinstein-Evron, 2012), Unit IX from Tabūn Cave (Jelinek et al., 1973; Shimelmitz and Kuhn, 2013), and Unit D (Layers 6 and 7) from Hummal (Wojtczak, 2011). Such assemblages, which are further characterized by a tendency towards the production of elongated blanks and points, a moderately high frequency of "Upper Paleolithic" tools (e.g., end scrapers, burins, truncations) relative to "Middle Paleolithic" ones (e.g, side scrapers, denticulates), and a paucity of classic ovoid Levallois products, are referred to variously as "Early Levantine Mousterian," "Tabūn D-type," or "Phase 1" (Culley et al., 2013; Meignen, 2000; Monigal, 2001; Shea, 2003). Chronometric dates place these industries between the end of Marine Isotope Stage (MIS) 8 and the middle of MIS 5, ca. 250 to 90kya (Clark et al., 1997; Mercier and Valladas, 2003; Mercier et al., 2007; Valladas et al., 2013). A similar phenomenon is also documented in the southern Caucasus. D. M. Tushabramishvili (1965: 55) and Liubin (1977: 95, 191) long ago recognized the laminar nature of the MP assemblages from the Georgian cave sites of Kudaro 1 (Layers 3 and 4), Kudaro 3 (Layer 4), Tsona (Layers 5 and 5a), and Djruchula (Cultural Layers 1 and 2). While Liubin (1977: 5, 8, 80-82, 92-95, 191; 1984: 64, 70; 1989: 92; Lioubine and Beliaeva, 2006: 80-83) referred to this complex variously as the "Kudarian Mousterian Culture", "Kudaro-Djruchulian Archaeological Culture", "Kudaro Group”, or "Djruchula-Kudarian Group”, Golovanova and Doronichev (2003: 118) prefer the term "Djurchulian" because, they argue, the eponymous site's 
larger sample size best represents the industry. Regardless, elongated points with various forms of retouch, including an apparently unique pattern of inverse retouch at the base and/or tip, are particularly common at these sites (Beliaeva and Liubin, 1998; Lubine et al., 1985; Meignen and Tushabramishvili, 2010; Tushabramishvili et al., 2007). Research demonstrates that, like many of their counterparts in the Levant, the laminar components of the assemblages from at least Djurchula, Kudaro 1, and Tsona exhibit a combination of both Levallois and Laminar methods of blade production (Meignen and Tushabramishvili, 2006, 2010; Tushabramishvili et al., 2007; Moncel et al., 2015). The cave of Hovk 1 in northern Armenia also preserves a handful of elongated retouched points, all of which appear to have been produced via Levallois reduction (Pinhasi et al., 2008: 813). Reliable chronometric dates for these assemblages are rare, but those that do exist are consistent with the Levantine data and point to occupations between the end of MIS 8 and into MIS 5, ca. 260 to 100kya (Golovanova and Doronichev, 2003: 78; Mercier et al., 2010; Pinhasi et al., 2011).

While the Bagratashen 1 points are thus consistent, at least on general typological grounds, with an early MP date, the OSL determinations clearly are not. Bearing in mind the caveats listed above, we do not think a late MP date should necessarily be dismissed out of hand. The regularity and diversity of basal modifications such as truncation and thinning at Bagratashen 1, for example, recall late MP assemblages like that from Ortvale Klde (Adler, 2002: 283-284). Perhaps significantly, and despite the presence of elongated points, Bagratashen 1 differs from Tabūn D-type and Djurchulian assemblages along several key technological dimensions. The frequency of blades, Levallois products, and platform faceting all fall below those seen among both the Djurchulian assemblages and Culley et al.'s (2013) sample of 12 Tabūn D-type assemblages from the Levant. Bagratashen 1 in fact lies outside the range of 
variability of all the major Levantine Mousterian facies for several indices (Table 11). The bifacial retouch so characteristic of elongated points from Djurchulian contexts is also absent at Bagratashen 1.

While local peculiarities in reduction techniques, blank modification, and the morphology of end products are apparent among southern Caucasian MP lithic assemblages, researchers have presumed some level of cultural association with nearby regions (particularly the Levant and Taurus/Zagros) based on perceived parallels in lithic technology (e.g., Adler and Tushabramishvili, 2004: 124; Beliaeva and Liubin, 1998: 41; Fourloubey et al., 2003: 10; Golovanova and Doronichev, 2003: 116-118, 2005: 5-13; Liagre et al., 2006: 13-17; Lioubine and Beliaeva, 2006: 80-83, 98). Meignen and Tushabramishvili (2010: 55), for instance, consider specific technological features among the lithics abandoned at Djurchula (e.g., laminar tendencies, elongated retouched points) as evidence for "blade-producing groups of the same technical tradition as the Hayonim/Hummal/Abou Sif [i.e., Tabūn D-type] people." The presence of a Near East "laminar tradition" (albeit with some indigenous idiosyncrasies) in the southern Caucasus implies an infusion of people and/or ideas from the south.

While it is tempting to treat lithic attributes as evidence for (or against) chrono-cultural relationships, the extent to which they actually signal cultural transmission remains unclear. Few dispute the social nature of technology, but there are, after all, only a limited number of ways one can reduce a cobble or retouch an elongated blank. It is thus certainly possible that temporally and socially unrelated knappers independently converged on similar core reduction strategies and formal tool types that say as much, or more, about responses to raw material size and distribution, site location and function, and mobility than they do about shared identity or chronological overlap (Clark and Riel-Salvatore, 2006). The presence of elongated retouched 
points at Bagratashen 1 in a (possibly) Late Pleistocene context may signal just such a phenomenon ${ }^{2}$. Fully testing these alternatives at Bagratashen 1 requires a complete morphotechnological analysis, additional chronometric dates and, more broadly, the excavation, analysis, and dating of more MP sites from multiple (but especially open-air) contexts.

\subsection{Conclusions}

It comes as no surprise to most Paleolithic archaeologists that instead of a largely undifferentiated, monolithic entity, a close examination of the MP record reveals a significant degree of regional variability spread out over nearly 200,000 years. The challenge, then, is to explain this variability and, in so doing, understand why MP adaptations were so very successful for so very long. If the frequency and variability of lithic debris is any indication, the southern Caucasus was home to numerous MP populations from at least the end of the Middle and into the Late Pleistocene. The region's rugged landscapes and heterogeneous habitats likely encouraged, if not required, these peoples to develop dynamic and diverse adaptive responses.

For these and other reasons, the importance of the southern Caucasus has been recognized for some time, though its immense potential has been muted by a scarcity of chronometric dates, imprecise stratigraphic control of early excavations, the selective retention of excavated materials, and funding shortages following the collapse of the Soviet Union. The archaeological assemblages produced under these circumstances are ill-equipped to address many of the questions raised by more recent methodological and theoretical advances, a situation that has consigned the region to an ancillary role in broader debates of MP behavior. This state of

\footnotetext{
${ }^{2}$ Sharon and Oron (2014: 183) make such an argument for the site of Nahal Mahanayeem Outlet (NMO) in Israel where Tabūn D-type characteristics (substantial numbers of elongated, though, in this case, unretouched, points) are found in a Late Pleistocene context, and they conclude "[c]hronologically, the elongated nature of the NMO artifacts suggests that the assemblage should be attributed to the Early 'Tabun D' stage of the Levantine Mousterian. This contradicts the dates obtained for the site placing it within the final stages of the Levantine MP. The NMO lithic assemblage does not herald a new cultural phase in the Levantine MP, nor should it be attributed to a defined stage. The typological composition of the assemblage is a direct outcome of the primary activity carried out at the site: processing the meat of large game."
} 
affairs is changing rapidly, and the accumulation over the past decade of studies on both curated and newly excavated materials testifies to the region's revitalized MP research program (Gasparyan et al., 2014).

While encouraging, the dearth of assemblages from well-controlled excavations and reliably dated contexts persists, and stratified open-air sites are still woefully underrepresented in the record. This makes it difficult to integrate the few detailed site-specific chronologies and behavioral models that do exist into regional- and evolutionary-scale comparative frameworks. Adler et al. (2006), for instance, argue that Late Pleistocene human groups at Ortvale Klde tuned their landscape use to the seasonal availability of resources, perhaps aggregating around strategically located caves and rockshelters to exploit particular game species during the winter while dispersing into smaller family units to utilize larger areas during the summer. The extent to which this reconstruction holds throughout the region, as they point out (Ibid: 92, 103), can only be assessed through "continued regional archaeological fieldwork and analysis" including, most prominently, "the open-air component of Palaeolithic settlement."

Researchers are also beginning to question the degree to which southern Caucasian lithic industries represent coherent cultural traditions maintained by groups with shared identities. The growing number of chronometric dates and the concomitant shift away from a culture historical approach has persuaded some that lithic variability is more likely the result of diachronic change and strategic responses to resource distribution (Adler, 2002: 357-358; Díez-Martín et al., 2009: 41). Shea (2014) goes even further and argues that all named MP lithic industries, including the southern Caucasus's Djurchulian, should be abandoned entirely.

We believe that Bagratashen 1 has much to offer in this context. While the OSL results should not be accepted uncritically, there are credible reasons to consider a Late Pleistocene age 
for the site's MP occupation. That the deposits are at least amenable to OSL analysis is crucial given the absence of fauna or other organic remains. The carbonates that permeate the sediments may provide at least a minimum age for the find horizon through U-series analyses. Bagratashen 1 is also one of only a handful of stratified open-air MP sites in all of the southern Caucasus and, to our knowledge, is singular among such sites in its low altitude setting (at only 457 masl), raw material inventory (a dominance of fine-grained volcanics to the near exclusion of other rock types, particularly flint and obsidian), and assemblage characteristics (primary reduction, formal tools, high frequency of cores). Based on a preliminary appraisal of the site's depositional history, we are confident that the composition and spatial patterning of the lithic assemblage is largely the result of human activity, even if they reflect a palimpsest of discrete events scattered over many years. Finally, the presence of "early" MP artifact types with possible "late" MP dates permits an evaluation of the utility of formal tool types and lithic reduction techniques as chronocultural markers. We therefore expect further excavations and analysis of Bagratashen 1 to reveal novel aspects of southern Caucasian MP lifeways.

\section{Acknowledgments}


This research is part of the Lori Depression Paleoanthropological Project. Members of the team not appearing as authors include Suren Kesejyan and Robert Ghukasyan. We are most grateful to Dr. Pavel Avetisyan and the Institute of Archaeology and Ethnography (National Academy of Sciences, Republic of Armenia) for unyieldingly supporting of our work. This work was supported by the National Science Foundation (BCS-0936385), the University of North Carolina at Greensboro (the Department of Anthropology Kupferer-Outwin Endowment, the Kohler Fund, and the Office of Research and Economic Development), the Armenian Branch of the Gfoeller Foundation, the Institute of Archaeology and Ethnography, and Earlham College (the Geology Department Ansel Gooding Endowment and the Earlham College Summer Research Fund). We extend a special thanks to John Shea for generously sharing his unpublished metric data on the sample of experimental spear points. Dan Adler was a valuable sounding board for several of the ideas presented here, and two anonymous referees provided constructive comments on an earlier version of this manuscript. We, of course, remain responsible for any and all errors.

\section{References}


Adler, D.S., 2002. Late Middle Palaeolithic Patterns of Lithic Reduction, Mobility, and Land Use in the Southern Caucasus, Ph.D. Dissertation, Department of Anthropology. Harvard University, Cambridge.

Adler, D.S., Bar-Oz, G., Belfer-Cohen, A., Bar-Yosef, O., 2006. Ahead of the game: Middle and Upper Palaeolithic hunting behaviors in the southern Caucasus. Current Anthropology 47, 89118.

Adler, D.S., Bar-Yosef, O., Belfer-Cohen, A., Tushabramishvili, N., Boaretto, E., Mercier, N., Valladas, H., Rink, W.J., 2008. Dating the demise: Neandertal extinction and the establishment of modern humans in the southern Caucasus. J. Hum. Evol. 55, 817-833.

Adler, D.S., Pinhasi, R., Gasparian, B., Tushabramishvili, N., Yeritsyan, B.G., 2009. Neandertal life-ways in the southern Caucasus. Abstracts of the Abric Romaní (1909-2009) International Workshop "The Neanderthal Home: Spatial and Social Behaviors" Tarragona - Capellades, October 6-9, 2009, 125-126.

Adler, D.S., Tushabramishvili, N., 2004. Middle Palaeolithic patterns of settlement and subsistence in the southern Caucasus, In: Conard, N.J. (Ed.), Settlement Dynamics of the Middle Paleolithic and Middle Stone Age. Kerns Verlag, Tübingen, pp. 91-132.

Adler, D.S., Wilkinson, K.N., Blockley, S., Mark, D.F., Pinhasi, R., Schmidt-Magee, B.A., Nahapetyan, S., Mallol, C., Berna, F., Glauberman, P.J., Raczyinski-Henk, Y., Wales, N., Frahm, E., Jöris, O., MacLeod, A., Smith, V.C., Cullen, V.L., Gasparian, B., 2014. Early Levallois technology and the Lower to Middle Paleolithic transition in the southern Caucasus. Science $345,1609-1613$.

Adler, D.S., Yeritsyan, B., Wilkinson, K., Pinhasi, R., Bar-Oz, G., Nahapetyan, S., Bailey, R., Schmidt, B.A., Glauberman, P., Wales, N., Gasparian, B., 2012. The Hrazdan Gorge Palaeolithic Project, 2008-2009, In: Avetisyan, P., Bobokhyan, A. (Eds.), Archaeology of Armenia in Regional Context, Proceedings of the International Conference dedicated to the 50th Anniversary of the Institute of Archaeology and Ethnography Held on September 15-17, 2009 in Yerevan, Armenia. NAS RA Gitutyn Publishing House, Yerevan, pp. 21-37.

Badalyan, R., Chataigner, C., Kohl, P., 2004. Trans-Caucasian obsidian: the exploitation of the soruces and their distribution, In: Sogona, A. (Ed.), A View from the Highlands: Archaeological Studies in Honor of Charles Burney. Peeters Publishing, Leuven, pp. 437-465.

Bader, O.N., Boriskovskij, P.I., Ivanova, I.K., Praslov, N.D., 1976. Materials on the results of the excavation of old stone age sites in the Soviet Union during 1974 and 1975. Early Man News (Tübingen) 1, 4-31.

Bar-Yosef, O., Kuhn, S.L., 1999. The big deal about blades: laminar technologies and human evolution. American Anthropologist 101, 322-338. 
Beliaeva, E.V., Liubin, V.P., 1998. The Caucasus-Levant-Zagros: possible relations in the Middle Paleolithic, In: Otte, M. (Ed.), Préhistoire d'Anatolie: Genese de deux monde. Études et Recherches Archéologiques de 1'Université de Liège 85, Liège, pp. 39-55.

Chataigner, C., Gratuze, B., 2014. New data on the exploitation of obsidian in the southern Caucasus (Armenia, Georgia) and eastern Turkey, Part 1: source characterization. Archaeometry $56,25-47$.

Clark, G.A., Riel-Salvatore, J., 2006. Observations on systematics in Paleolithic archaeology, In: Hovers, E., Kuhn, S.L. (Eds.), Transitions before the transition: evolution and stability in the Middle Paleolithic and Middle Stone Age. Springer, New York, pp. 29-56.

Clark, G.A., Schuldenrein, J., Donaldson, M.L., Schwarcz, H.P., Rink, W.J., Fish, S.K., 1997. Chronostratigraphic contexts of Middle Paleolithic horizons at the 'Ain Difla Rockshelter (WHS 634), west-central Jordan, In: Rollefson, G.O., Kafafi, Z.A.-K., Gebel, H.-G. (Eds.), The Prehistory of Jordan, II: Perspectives from 1997. Ex oriente, Berlin, pp. 77-100.

Cohen, V.Y., Stepanchuk, V.N., 1999. Late Middle and early Upper Paleolithic evidence from the East European Plain and Caucasus: a new look at variability, interactions, and transitions. Journal of World Prehistory 13, 265-319.

Conard, N.J., Bolus, M., Münzel, S.C., 2012. Middle Paleolithic land use, spatial organization and settlement intensity in the Swabian Jura, southwestern Germany. Quaternary International 247, 236-245.

Conard, N.J., Soressi, M., Parkington, J.E., Wurz, S., Yates, R., 2004. A unified lithic taxonomy based on patterns of core reduction. South African Archaeological Bulletin 59, 12-16.

Copeland, L., 1983. Levallois/non-Levallois determinations in the Early Levant Mousterian: problems and questions for 1983 Paléorient 9, 15-27.

Culley, E.V., Popescu, G., Clark, G.A., 2013. An analysis of the compositional integrity of the Levantine Mousterian facies. Quaternary International 300, 213-233.

d'Errico, F., 2003. The invisible frontier: a multiple-species model for the origin of behavioral modernity. Evolutionary Anthropology 12, 188-202.

Daujeard, C., Fernandes, P., Guadelli, J.-L., Monchel, H.-M., Santagata, C., Raynal, J.-P., 2012. Neanderthal subsistence strategies in Southeastern France between the plains of the Rhone Valley and the mid-mountains of the Massif Central (MIS 7 to MIS 3). Quaternary International 252, 32-47.

Delagnes, A., Meignen, L., 2006. Diversity of lithic production systems during the Middle Paleolithic in France: are there any chronological trends?, In: Hovers, E., Kuhn, S.L. (Eds.), Transitions before the transition: evolution and stability in the Middle Paleolithic and Middle Stone Age. Springer, New York, pp. 85-107. 
Delagnes, A., Rendu, W., 2011. Shifts in Neandertal mobility, technology and subsistence strategies in western France. Journal of Archaeological Science 38, 1771-1783.

Díez-Martín, F., Martínez Molina, K., García Garriga, J., Gómez González, J.Á., Cáceres, I., Allué Martí, E., Sánchez Yustos, P., Yravedra, J., 2009. El Paleolítico Medio en el Cáucaso Meridional: la Cueva Doble (valle de Tsutskhvati, República de Georgia). Zephyrus LXIII, 1544.

Doronichev, V.B., 1993. Mustierskie industrii Bol'shogo Kavkaza (Mousterian industries of the Greater Caucasus). Peterburgskiy Arkheologicheskiy Vestnik 7, 14-24.

Doronichev, V.B., Golovanova, L.V., 2003. Bifacial tools in the Lower and Middle Paleolithic of the Caucasus and their contexts, In: Soressi, M., Dibble, H.L. (Eds.), Multiple Approaches to the Study of Bifacial Technologies. University of Pennsylvania Museum of Archaeology and Anthropology, Philadelphia, pp. 77-107.

Doronicheva, E.V., Shackley, M.S., 2014. Obsidian exploitation strategies in the Middle and Upper Paleolithic of the northern Caucasus: new data from Mesmaiskaya Cave. PaleoAnthropology 2014, 565-585.

Dusseldorp, G.L., 2012. Studying prehistoric hunting proficiency: applying Optimal Foraging Theory to the Middle Palaeolithic and Middle Stone Age. Quaternary International 252, 3-15.

Egeland, C.P., Gasparian, B., Arakelyan, D., Nicholson, C.M., Petrosyan, A., Ghukasyan, R., Byerly, R.M., 2014. Reconnaissance survey for Palaeolithic sites in the Debed River Valley, northern Armenia. Journal of Field Archaeology 39, 370-386.

Egeland, C.P., Nicholson, C.M., Gasparian, B., 2010. Using GIS and ecological variables to identify high potential areas for paleoanthropological survey: an example from northern Armenia. Journal of Ecological Anthropology 14, 87-96.

Eren, M.I., Greenspan, A., Sampson, C.G., 2008. Are Upper Paleolithic blade cores more productive than Middle Paleolithic discoidal cores? A replication experiment. J. Hum. Evol. 55, 952-961.

Fourloubey, C., Beauval, C., Colonge, D., Liagre, J., Ollivier, V., Chataigner, C., 2003. La Páleolithique en Arménie: état des connaissances acquises et données recent. Paléorient 29, 5-18. Frahm, E., Feinberg, J.M., Schmidt-Magee, B.A., Wilkinson, K., Gasparyan, B., Yeritsyan, B.G., Karapetian, S., Meliksetian, K., Muth, M.J., Adler, D.S., 2014. Sourcing geochemically identical obsidian: multiscalar magnetic variations in the Gutansar volcanic complex and implications for Palaeolithic research in Armenia. Journal of Archaeological Science 47, 164-178.

Gamble, C., 1999. The Palaeolithic Societies of Europe. Cambridge University Press, Cambridge. 
Gasparyan, B., Egeland, C.P., Adler, D.S., Pinhasi, R., Glauberman, P., Haydosyan, H., 2014. The Middle Paleolithic occupation of Armenia: summarizing old and new data, In: Gasparyan, B., Arimura, M. (Eds.), Stone Age of Armenia: A Guide-book to the Stone Age Archaeology in the Republic of Armenia. Center for Cultural Resource Studies, Kanazawa University, Kanazawa, pp. 65-105.

Gaudzinski-Windheuser, S., Roebroeks, W., 2011. On Neanderthal subsistence in last interglacial forested environments in northern Europe, In: Conard, N.J., Richter, J., Condemi, S. (Eds.), Neanderthal lifeways, subsistence and technology: one hundred fifty years of Neanderthal study. Springer, New York, pp. 61-71.

Ghukasyan, R., Colonge, D., Nahapetyan, S., Ollivier, V., Gasparyan, B., Monchot, H., Chataigner, C., 2011. Kalavan-2 (north of Lake Sevan, Armenia): a new late Middle Paleolithic site in the the Lesser Caucasus. Archaeology, Ethnology, and Anthropology of Eurasia 38, 3951 .

Gile, L.H., Peterson, F.F., Grossman, R.B., 1966. Morphological and genetic sequences of carbonate accumulation in desert soils. Soil Science 101, 347-360.

Golovanova, L.V., Doronichev, V.B., 2003. The Middle Paleolithic of the Caucasus. Journal of World Prehistory 17, 71-140.

Golovanova, L.V., Doronichev, V.B., 2005. Ekologicheskiye nishi i modeli adaptatsii v srednem paleolite Kavkaza (Ecological niches and models of adaptation in the Middle Paleolithic of the Caucasus), In: I., M.I. (Ed.), Materiali i Issledovaniya po Arkeologii Kubani (Materials and Investigations on the Archaeology of Kuban). Kuban State University, Krasnodar, pp. 3-72.

Grayson, D.K., Delpech, F., 2003. Ungulates and the Middle-to-Upper Paleolithic transition at Grotte XVI (Dordogne, France). Journal of Archaeological Science 30, 1633-1648.

Gulisahvili, V.Z., Mahatadze, L.B., Prilipko, L.I., 1975. Rastitelnost Kavkaza (Vegetation of the Caucasus). Nauka, Moscow.

Henry, A.G., Brooks, A.S., Piperno, D.R., 2014. Plant foods and the dietary ecology of Neanderthals and early modern humans. J. Hum. Evol. 69, 44-54.

Hovers, E., Belfer-Cohen, A., 2006. "Now you see it, now you don't"-Modern human behavior in the Middle Paleolithic, In: Hovers, E., Kuhn, S.L. (Eds.), Transitions before the transition: evolution and stability in the Middle Paleolithic and Middle Stone Age. Springer, New York, pp. 295-304.

Hovers, E., Belfer-Cohen, A., 2013. On variability and complexity: lessons from the Levantine Middle Paleolithic record. Current Anthropology 54, S337-S357.

Hughes, S.S., 1998. Getting to the point: evolutionary change in prehistoric weaponry. Journal of Archaeological Method and Theory 5, 345-408. 
Inizan, M.-L., Reduron-Ballinger, M., Roche, H., Tixier, J., 1999. Technology and Terminology of Knapped Stone (trans. Jehanne Féblot-Augustins). CREP, Nanterre.

Jain, M., Bøtter-Jensen, L., Singhvi, A.K., 2003. Dose evaluation using multiple-aliquot quartz OSL: test of methods and a new protocol for improved accuracy and precision. Radiation Measurements 37, 67-80.

Jelinek, A.J., 1982. The Middle Palaeolithic in the southern Levant, with comments on the appearance of modern Homo sapiens, In: Ronen, A. (Ed.), The Transition from Lower to Middle Palaeolithic and the Origin of Modern Man. British Archaeological Reports International Series 151, Oxford, pp. 57-104.

Jelinek, A.J., Frarrand, W.R., Haas, G., Horowitz, A., Goldberg, P., 1973. New excavations at the Tabun Cave, Mount Caramel, Israel, 1967-1972: a preliminary report. Paléorient 1, 151-183.

Joannin, S., Cornée, J.J., Münch, P., Fornari, M., Vasiliev, I., Krijgsman, W., Nahapetyan, S., Gabrielyan, I., Ollivier, V., Roiron, P., Chataigner, C., 2010. Early Pleistocene climate cycles in continental deposits of the Lesser Caucasus of Armenia inferred from palynology, magnetostratigraphy, and Ar-40/Ar-39 dating. Earth and Planetary Science Letters 291, 149-158.

Kozlowski, J.K., 1998. The Middle and the early Upper Paleolithic around the Black Sea, In: Akazawa, T., Aoki, K., Bar-Yosef, O. (Eds.), Neandertals and Modern Humans in Western Asia. Plenum Press, New York, pp. 461-482.

Kozłowski, J.K., 2014. Middle Palaeolithic variability in Central Europe: Mousterian vs Micoquian. Quaternary International 326-327, 344-363.

Krever, V., Zazanashvili, N., Junguis, H., Williams, L., Petelin, D., 2001. Biodiversity of the Caucasus Ecoregion. World Wild Life Fund for Nature, Moscow.

Kuhn, S.L., 1995. Mousterian Lithic Technology: An Ecological Perspective. Princeton University Press, Princeton.

Kuhn, S.L., 2012. Emergent patterns of creativity and innovation in early technologies, In: Elias, S. (Ed.), Origins of Human Innovation and Creativity. Elsevier, Amsterdam, pp. 69-87.

Kuhn, S.L., 2013. Roots of the Middle Paleolithic in Eurasia. Current Anthropology 54, S255S268.

Kuhn, S.L., Hovers, E., 2006. General introduction, In: Hovers, E., Kuhn, S.L. (Eds.), Transitions before the transition: evolution and stability in the Middle Paleolithic and Middle Stone Age. Springer, New York, pp. 1-11.

Kuhn, S.L., Stiner, M.C., 2006. What's a mother to do? The division of labor among Neandertals and modern humans in Eurasia. Current Anthropology 47, 953-980. 
Le Bourdonnec, F-X., Nomade, S., Poupeau, G., Guillou, H., Tushambramishvili, N., Moncel, M-H., Pleurdeau, D., Agapishvili, T., Voinchet, P., Mgeladze, A., Lordkipanidze, D., 2012. Multiple origins of Bondi Cave and Ortvale Klde (NW Georgia) obsidians and human mobility in Transcaucasia during the Middle and Upper Palaeolithic. Journal of Archaeological Science 39, 1317-1330.

Liagre, J., Gasparyan, B., Ollivier, V., Nahapetyan, S., 2006. Angeghakot-1 and the identification of the Mousterian cultural facies of "Yerevan points" type in the southern Caucasus. Paléorient 32, 5-18.

Lioubine, V.P., Beliaeva, E.V., 2006. Rannyaya Prehistoria Kavkaza. Russian Academy of Sciences, St. Petersburg.

Liubin, V.P., 1977. Must'yerskiye kul'tury Kavkaza (Mousterian Cultures of the Caucasus). Nauka, Leningrad.

Liubin, V.P., 1984. Ranniy paleolit Kavkaza (Early Paleolithic of the Caucasus), In: Boriskovsky, P.I. (Ed.), Paleolit SSSR (Paleolithic of Russia). Nauka, Moscow, pp. 45-93.

Liubin, V.P., 1989. Paleolit Kavkaza (Paleolithic of the Caucasus), In: Boriskovsky, P.I. (Ed.), Paleolit Kavkaza i Sredney Azii (Paleolithic of the Caucasus and northern Asia) Nauka, Leningrad, pp. 9-142.

Lubine, V.P., Tcherniachovski, A.G., Barychnikov, G.F., Levkovskaia, G.M., Selivanova, N.B., 1985. La Grotte de Koudaro I: résultats de recherches pluridisciplinaires. L'anthropolgie 89, 159180.

Marks, A.E., Chabai, V.P., 2006. Stasis and change during the Crimean Middle Paleolithic, In: Hovers, E., Kuhn, S.L. (Eds.), Transitions before the transition: evolution and stability in the Middle Paleolithic and Middle Stone Age. Springer, New York, pp. 121-135.

Marks, A.E., Hietala, H.J., Williams, J.K., 2001. Tool standardization in the Middle and Upper Palaeolithic: a closer look. Cambridge Archaeological Journal 11, 17-44.

McPherron, S.J.P., 2005. Artifact orientations and site formation processes from total station proveniences. Journal of Archaeological Science 32, 1003-1014.

Meignen, L., 1994. Paléolithique moyen au Proche-Orient: le phénomène laminaire, In: Révillion, S., Tuffreau, A. (Eds.), Les Industries Laminaires au Paléolithique Moyen. CNRS, Paris, pp. 125-159.

Meignen, L., 1998. Hayonim Cave lithic assemblages in the context of the Near Eastern Middle Paleolithic: a preliminary report, In: Akazawa, T., Aoki, K., Bar-Yosef, O. (Eds.), Neandertals and Modern Humans in Western Asia. Plenum Press, New York, pp. 165-180.

Meignen, L., 2000. Early Middle Paleolithic blade technology in southwestern Asia. Acta Anthropologica Sinica Supplment 19, 158-168. 
Meignen, L., 2011. The contribution of Hayonim Cave assemblages to the understanding of the so-called Early Levantine Mousterian, In: Le Tensorer, J.-M., Jagher, R., Otte, M. (Eds.), The Lower and Middle Palaeolithic in the Middle East and Neighbouring Regions. ERAUL, Liège, pp. 85-100.

Meignen, L., Bar-Yosef, O., Speth, J.D., Stiner, M.C., 2006. Middle Paleolithic settlement patterns in the Levant, In: Hovers, E., Kuhn, S.L. (Eds.), Transitions before the transition: evolution and stability in the Middle Paleolithic and Middle Stone Ag. Springer, New York, pp. 149-169.

Meignen, L., Tushabramishvili, N., 2006. Paléolithique moyen laminaire sur les flancs sud du Caucase: productions lithiques et fonctionnement du site de Djruchula (Géorgie). Paléorient 32, 81-104.

Meignen, L., Tushabramishvili, N., 2010. Djruchula Cave, on the southern slopes of the Great Caucasus: an extension of the Near Eastern Middle Paleolithic Blady Phenomenon to the North. Journal of The Israel Prehistoric Society 40, 35-61.

Mellars, P., 1996. The Neanderthal Legacy: An Archaeological Perspective from Western Europe. Princeton University Press, Princeton.

Mercier, N., Valladas, H., 2003. Reassessment of TL age estimates of burnt flints from the Paleolithic site of Tabun Cave, Israel. J. Hum. Evol. 45, 401-409.

Mercier, N., Valladas, H., Froget, L., Joron, J.L., Reyss, J.L., Weiner, S., Goldberg, P., Meignen, L., Bar-Yosef, O., Belfer-Cohen, A., Chech, A., Kuhn, S.L., Stiner, M.C., Tillier, A.M., Arensburg, B., Vandermeersch, B., 2007. Hayonim Cave: a TL-based chronology for this Levantine Mousterian sequence. Journal of Archaeological Science 34, 1064-1077.

Mercier, N., Valladas, H., Meignen, L., Joron, J.-L., Tushabramishvili, N., Adler, D.S., BarYosef, O., 2010. Dating the early Middle Palaeolithic laminar industry from Djruchula Cave, Republic of Georgia. Paléorient 36, 163-173.

Moncel, M-H., Pleurdeau, D., Pinhasi, R., Yeshurun, R., Agapishvili, T., Chevalier, T., Lebourdonnce, F-X., Poupeau, G., Nomade, S., Jennings, R., Higham, T., Tushubramishvili, N., Lordkipanidze, D., 2015. The Middle Palaeolithic record of Georgia: a synthesis of the technological, economic and paleoanthropological aspects. Anthropologie LIII, 93-125.

Monigal, K., 2001. Lower and Middle Paleolithic blade industries and the dawn of the Upper Paleolithic in the Levant. Archaeology, Ethnology, and Anthropology of Eurasia 1, 11-24.

Monigal, K., 2002. The Levantine Leptolithic: Blade Production from the Lower Paleolithic to the Dawn of the Upper Paleolithic, Ph.D. Dissertation, Department of Anthropology. Southern Methodist University, Dallas. 
Münzel, S.C., Conard, N.J., 2004. Change and continuity in subsistence during the Middle and Upper Palaeolithic in the Ach Valley of Swabia (South-west Germany). Int. J. Osteoarchaeol. 14, 225-243.

Nioradze, M., 1992. Peshernie stoyanki drevnekamennogo veka v ushelie reki Tskaltsitela (Palaeolithic Cave Sites of the Tskhaltsitela River Gorge), In: Tushabramishvili, D.M. (Ed.), Paleolit Kavkaza i sopredel'nikh territory (Palaeolithic Caves of the Caucasus and Adjacent Regions). Metsnereba, Tbilisi, pp. 55-60.

Panichkina, M.Z., 1950. Paleolit Armenii (The Paleolithic of Armenia). Nauka, Leningrad. Pinhasi, R., Gasparian, B., Nahapetyan, S., Bar-Oz, G., Weissbrod, L., Bruch, A.A., Hovsepyan, R., Wilkinson, K., 2011. Middle Palaeolithic human occupation of the high altitude region of Hovk-1, Armenia. Quaternary Science Reviews 30, 3846-3857.

Pinhasi, R., Gasparian, B., Wilkinson, K., Bailey, R., Bar-Oz, G., Bruch, A.A., Chataigner, C., Hoffmann, D., Hovsepyan, R., Nahapetyan, S., Pike, A.W.G., Schreve, D., Stephens, M., 2008. Hovk 1 and the Middle and Upper Paleolithic of Armenia: a preliminary framework. J. Hum. Evol. 55, 803-816.

Pleurdeau, D., Tushabramishvili, N., Nioradze, M., de Lumley, H., Lordkipanidze, D., 2007. Les assemblages lithiques du Paléolithique moyen de Géorgie. L'anthropolgie 111, 400-431.

Prescott, J.R., Hutton, J.T., 1994. Cosmic ray contributions to does rates for Luminescence and ESR dating: large depths and long-terms variations. Radiation Measurements 23, 497-500.

Reimer, P.J., Bard, E., Bayliss, A., Beck, J.W., Blackwell, P.G., Bronk Ramsey, C., Buck, C.E., Cheng, H., Edwards, R.L., Friedrich, M., Grootes, P.M., Guilderson, T.P., Halfidason, H., Hajdas, I., Hatté, C., Heaton, T.J., Hoffmann, D.L., Hogg, A.G., Hughen, K.A., Kaiser, K.F., Kromer, B., Manning, S.W., Niu, M., Reimer, R.W., Richards, D.A., Scott, E.M., Southon, J.R., Staff, R.A., Turney, C.S.M., van der Plicht, J., 2013. IntCal13 and Marine13 radiocarbon age calibration curves 0-50,000 years cal BP. Rardiocarbon 55, 1869-1887.

Ruebens, K., 2013. Regional behaviour among late Neanderthal groups in Western Europe: A comparative assessment of late Middle Palaeolithic bifacial tool variability. J. Hum. Evol. 65, 341-362.

Sardarian, S.A., 1954. Paleolit v Armenii (The Paleolithic in Armenia). Armenian SSR Academy of Sciences, Yerevan.

Shea, J., 2003. The Middle Paleolithic of the East Mediterranean Levant. Journal of World Prehistory 17, 313-394.

Shea, J.J., 2006. The origins of lithic projectile technology: evidence from Africa, the Levant, and Europe. Journal of Archaeological Science 33, 823-846. 
Shea, J.J., 2008. Transitions or turnovers? Climatically-forced extinctions of Homo sapiens and Neanderthals in the east Mediterranean Levant. Quaternary Science Reviews 27, 2253-2270.

Shimelmitz, R., Kuhn, S.L., 2013. Early Mousterian Levallois technology in Unit IX of Tabun Cave. PaleoAnthropology 2013, 1-27.

Shott, M.J., 1997. Stones and shafts redux: the metric discrimination of chipped-stone dart and arrow points. American Antiquity 62, 86-101.

Sisk, M.L., Shea, J.J., 2009. Experimental use and quantitative performance analysis of triangular flakes (Levallois points) used as arrowheads. Journal of Archaeological Science 36, 2039-2047.

Sisk, M.L., Shea, J.J., 2011. The African origin of complex projectile technology: an analysis using tip cross-sectional area and perimeter. International Journal of Evolutionary Biology 2011, Article ID 968012.

Sitzia, L., Bertran, P., Boulonge, S., Brenet, M., Crassard, R., Delagnes, A., Frouin, M., Hatté, C., Jaubert, J., Khalidi, L., Messager, E., Mercier, N., Meunier, A., Peigné, S., Queffelec, A., Tribolo, C., Macchiarelli, R., 2012. The paleoenvironment and lithic taphonomy of Shi'Bat Dihya 1, a Middle Paleolithic site in Wadi Surdud, Yemen. Geoarchaeology 27, 471-491.

Stiner, M.C., Kuhn, S.L., 1992. Subsistence, technology, and adaptive variation in Middle Paleolithic Italy. American Anthropologist 94, 306-339.

Thomas, D.H., 1978. Arrowheads and atlatl darts: how the stones got the shaft. American Antiquity 43, 461-472.

Thompson, E., 2009. Acheulean artifact accumulation and early hominin land use, Garden Route Casino Road, Pinnacle Point, South Africa. Geoarchaeology 24, 402-428.

Treadwell-Steitz, C., McFadden, L.D., 2000. Influence of parent material and grain size on carbonate coatings in gravelly soils, Palo Duro Wash, New Mexico. Geoderma 94, 1-22.

Tushabramishvili, D.M., 1965. Itogi rabot paleoliticheskoy ekspeditsii Kviril'skogo ushchel'ya (Chiaturskiy Rayon Gruzinskoy SSR) za 1963-1964 (Results of work for 1963-1964 of the Paleolithic expedition of the Kvirila Gorge [Chiatur Region of the Georgian SSR]), In: Vaidov, R.M. (Ed.), Materiali Sessii, Posvyashchennikh Itogam Arkheologicheskikh i Entograficheskikh Issledovaniy 1964 goda v SSSR (Tezisi Dokladov) (Materials of the Session Devoted to the Results of Archaeological and Ethnographical Investigation of the year 1964 in the USSR [Abstracts of the Reports]). Azerbaijan SSR Academy of Sciences Press, Baku, pp. 55-56.

Tushabramishvili, D.M., 1984. Paleolit Gruzii (The Paleolithic of Georgia). VestnikGosudarstvennogo Muzeia Gruzii 37B, 5-27. 
Tushabramishvili, N., Pleurdeau, D., Moncel, M.-H., Mgeladze, A., 2007. Le complexe Djruchula-Koudaro au sud Caucase (Géorgie). Remarques sur les assemblages lithiques pléistocènes de Koudaro I, Tsona et Djruchula. Anthropologie 45, 1-18.

Valladas, H., Mercier, N., Hershkovitz, I., Zaidner, Y., Tsatskin, A., Yeshurun, R., Vialettes, L., Joron, J.-L., Reyss, J.-L., Weinstein-Evron, M., 2013. Dating the Lower to Middle Paleolithic transition in the Levant: A view from Misliya Cave, Mount Carmel, Israel. J. Hum. Evol. 65, 585-593.

Volodicheva, N., 2002. The Caucasus, In: Shahgedanova, M. (Ed.), The Physical Geography of Northern Eurasia. Oxford University Press, Oxford, pp. 350-376.

Wojtczak, D., 2011. Hummal (central Syria) and its eponymous industry, In: Le Tensorer, J.-M., Jagher, R., Otte, M. (Eds.), The Lower and Middle Palaeolithic in the Middle East and Neighbouring Regions. ERAUL, Liège, pp. 289-307.

Yeritsyan, B.G., 1970. Yerevanskaya peshchernaya stoyanka i mesto sredi drevneishih pamyatnikov Kavkaza (The Yerevan Cave Site and Its Position Among the Early Sites of the Caucasus), Ph.D. Dissertation, Department of Archaeology. University of Moscow, Moscow.

Yeritsyan, B.G., 1971. Yerevanskaya peshchera i ee kul'tura (Yerevan cave and its culture), Tezisi dokladov posvyashchennikh itogam polevikh arkheologicheskikh issledovaniy v SSSR v 1970 g.- arkheologicheskiye sektsii (Abstracts of Reports devoted to the Fieldwork Archaeological Investigations in the USSR in 1970-Archeological Sessions. Metsniereba, Tbilisi, pp. 239-240.

Yeritsyan, B.G., 1972a. K voprosu o videlenii nizhnepaleoliticheskikh kultur na Armyanskom nagorii (On the question of allocation of Lower Paleolithic cultures in the Armenian Highlands), In: Ismalov, U.I. (Ed.), Kamenniy vek Sredney Asii i Kazakhsstana: Tezisi dokladov soveshchaniya (Stone Age of Middle Asia and Kazakhstan: Abstracts of the reports of the session). Uzbekistan SSR Academy of Sciences, Tashkent, pp. 24-28.

Yeritsyan, B.G., 1972b. Nekotoriye ossobennosti namerennogo rassecheniya orudiy must'erskoy epokhi, po materialam Yerevanskoy peshchernoy stoyanki) (Some features of intentional truncation of Mousterian tools, based on the materials of Yerevan cave site), In: Kruglikova, I.T. (Ed.), Kratkiye soobshcheniya Instituta Arkheologii (Briefs of the Institute of Archaeology), N131, Kamenniy vek (Stone Age). Nauka, Moscow, pp. 53-60.

Yeritsyan, B.G., 1972c. Nizhnepaleoliticheskaya peshchera Lusakert 1 (Armeniya) (The Lower Paleolithic cave of Lusakert 1), Tezisi dokladov na sektsiyakh, posvyashchennikh itogam polevikh issledovaniy $1971 \mathrm{~g}$. (Abstracts of Reports in Sessions devoted to the Fieldwork Investigations in 1971). USSR Academy of Sciences Institute of Archaeology, Moscow, pp. 239240.

Yeritsyan, B.G., 1976. The life style and habitat of Middle Paleolithic man in Transcaucasia, Reports and communications by archaeologists of the USSR at IX International Congress of 
Prehistoric and Protohistoric Sciences. Institute of Archaeology of the Academy of Sciences of the USSR, Moscow, pp. 14-17.

Yeritsyan, B.G., 1979. Lusakert-1-in karayri ashelyan mshakuyty (Acheulian culture of the Lusakert-1 cave), In: Arakelyan, B.N. (Ed.), Haykakan SSH-um 1977-1978 tt. dashtayin hnagitakan ashkhatankneri ardyunknerin nvirvats zekutsumneri tezisner (Abstracts of Reports devoted to the Archaeological Fieldwork Results in 1977-1978 in the Armenian SSR). Armenian SSR Academy of Sciences, Yerevan, pp. 14-15.

Yeritsyan, B.G., Khudaverdyan, A., 2013. The Paleolithic of Armenia: the retrospective of anthropological findings. Abstracts of the International Conference "Historical and Cultural Heritage and Contemporaneity" Gyumri, October 4-6, 2013, 19-23.

Yeritsyan, B.G., Korobkov, I.I., 1979. Issledovanie paleoliticheskikh pamyatnikov v srednem techenii reki Razdan (Study of Paleolithic sites in the middle stream of the Hrazdan River), In: Ribakov, B.A. (Ed.), Arkheologicheskiye otkritiya 1978 goda (Archaeological Discoveries of the year 1978). Nauka, Moscow, pp. 519-520.

Zaidner, Y., Weinstein-Evron, M., 2012. Making a point: the Early Middle Palaeolithic tool assemblage of Misliya Cave, Mount Carmel, Israel. Before Farming 2012, Article 1, 1-23. 


\section{Figure captions}

Figure 1. The southern Caucasus with major landforms, MP sites, and obsidian sources identified.

Figure 2. Topographic map showing the location of Bagratashen 1 relative to local landforms and the two closest villages (Bagratashen and Ptghavan).

Figure 3. Composite stratigraphic summary of Trench 1.

Figure 4. View of Trench 1 at the end of the 2010 excavation season. The main find horizon (Archaeological Layer 3b) lies at and just below the OSL sampling locations (indicated by the circular holes).

Figure 5. Topographic map showing the location of Trench 1, Trench 2, and excavation unit designations.

Figure 6. View of Trench 1 (right) and Trench 2 (left) at the end of the 2011 excavation season.

Figure 7. Bar graph showing the relative frequency of particle size classes in the Bagratashen 1 lithic assemblage $(n=500)$.

Figure 8. (a) Stereogram showing the orientation and inclination of lithic particles with clear long axes and (b) Rose diagram showing the orientation of lithic particles with clear long axes.

Figure 9. Vertical and horizontal distribution of finds within Archaeological Layer 3b. Red lines represent refits; triangles show location of OSL samples.

Figure 10. Pie chart showing relative frequencies of raw material types in the Bagratashen 1 lithic assemblage $(n=434)$.

Figure 11. Middle Paleolithic cores from Bagratashen 1. $a=2010-225$, unidirectional parallel core, dacite; $b=2010-329$, bidirectional parallel core, dacite; $c=2010-700.8$, inclined core, dacite; $d=2011-787$, irregular (exhausted) core, dacite; $e=2010-542$, initial core, dacite. Scale bars $=1 \mathrm{~cm}$.

Figure 12. Examples of elongated points from the Bagratashen 1 lithic assemblage. $a=2011$ 1418 , dacite; $b=2009-10$, basalt. Scale bars $=2 \mathrm{~cm}$. Note: $2009-10$ is a surface find. 
Figure 13. Examples of elongated points from the Bagratashen 1 lithic assemblage. $a=2010$ 459 , flint; $b=2010-771$, dacite. Scale bars $=2 \mathrm{~cm}$.

Figure 14. Boxplots comparing (a) TCSP and (b) TCSA among the Bagratashen 1 points ( $=17$; does not include surface finds from Table 8), ethnographic arrowheads $(n=118$; Thomas, 1978: Table 2), ethnographic atlatl darts $(\mathrm{n}=40$; Shott, 1997: Table 1; Thomas, 1978: Table 3), and experimental thrusting spear tips $(n=28$; Shea, unpublished data).

Figure 15. Examples of tools from the Bagratashen 1 lithic assemblage. $a=2010-691$, side scraper, dacite; $b=2011-1436$, side scraper, dacite; $c=2011-789$, notched piece, dacite; $d=$ 2010-656, notched piece, dacite; $\mathrm{e}=2011-1229$, end scraper on débordant, dacite. Scale bars $=2$ $\mathrm{cm}$.

Figure 16. Pie chart showing relative frequency of platform types in the Bagratashen 1 lithic assemblage $(\mathrm{n}=129)$. 
Table 1. Description of metric attributes for the Bagratashen 1 lithic assemblage.

\begin{tabular}{|c|c|}
\hline Attribute & Description \\
\hline \multirow[t]{2}{*}{ Length } & Cores: largest parallel distance along axis of the dominant flaking surface \\
\hline & $\begin{array}{l}\text { Flakes/blanks: distance from proximal to distal end that runs parallel to axis of propagation and perpendicular to striking platform at } \\
\text { point of impact; measured on ventral surface }\end{array}$ \\
\hline Maximum Length & $\begin{array}{l}\text { Flakes/blanks: maximum length of flake axis measured from striking platform at point of impact to most distant distal point of flake; } \\
\text { measured on ventral surface }\end{array}$ \\
\hline \multirow[t]{2}{*}{ Midpoint Width } & Cores: distance at midpoint of piece perpendicular to length axis of the dominant flaking surface \\
\hline & Flakes/blanks: distance at midpoint of piece perpendicular to the axis of propagation running from one lateral edge to the other \\
\hline Maximum Width & Flakes/blanks: maximum width perpendicular to axis of propagation from one lateral side to the other \\
\hline Width & Flakes/blanks: maximum width perpendicular to flake axis \\
\hline \multirow[t]{2}{*}{ Midpoint Thickness } & Cores: thickness at midpoint of length perpendicular to both axis of dominant flaking surface and axis of core width \\
\hline & Flakes/blanks: thickness at midpoint of length perpendicular to axis of propagation running from dorsal to ventral surface \\
\hline Maximum thickness & Flakes/blanks: maximum thickness running from dorsal to ventral surface \\
\hline Tip angle & Points only: angle at which lateral edges converge at tip \\
\hline
\end{tabular}


Table 2. Scoring system for post-depositional modifications in the Bagratashen 1 lithic assemblage ${ }^{1}$.

\begin{tabular}{|c|c|c|c|c|}
\hline Modification & Score $=0$ & Score $=1$ & Score $=2$ & Score $=3$ \\
\hline Carbonate encrustation & None & $\begin{array}{l}\text { Visible to the eye, no } \\
\text { features obscured }\end{array}$ & Features obscured & N/A \\
\hline Weathering/patina & None & $\begin{array}{l}\text { Original surface color } \\
\text { visible between patches of } \\
\text { patina }\end{array}$ & $\begin{array}{l}\text { More patina than original } \\
\text { color }\end{array}$ & No original color remaining \\
\hline Polish & None & $\begin{array}{l}\text { Reflects light slightly when } \\
\text { rotated }\end{array}$ & Continuously reflects light & $\begin{array}{l}\text { Every aspect of surface } \\
\text { appears shiny }\end{array}$ \\
\hline Rounding & None & $\begin{array}{l}\text { Visible under light } \\
\text { magnification }\end{array}$ & $\begin{array}{l}\text { Visible to the eye, no features } \\
\text { obscured }\end{array}$ & Features obscured \\
\hline
\end{tabular}

1. Modified from Thompson (2009). 
Table 3. OSL data for the Bagratashen 1 MP find horizon ${ }^{1,2,3,4,5,6}$.

\begin{tabular}{|c|c|c|c|c|c|c|c|c|}
\hline Lab number & $\begin{array}{l}\text { Equivalent dose } \\
\text { (Grays) }\end{array}$ & $\mathrm{U}(\mathrm{ppm})$ & Th (ppm) & $\mathrm{K}_{2} \mathrm{O}(\%)$ & $\mathrm{H}_{2} \mathrm{O}(\%)$ & $\begin{array}{l}\text { Cosmic dose } \\
\text { (mGrays/yr) }\end{array}$ & $\begin{array}{l}\text { Total dose } \\
\text { (mGrays/yr) }\end{array}$ & OSL age \\
\hline UIC 2830 & $133.85 \pm 7.99$ & $3.9+0.1$ & $7.9+0.1$ & $2.09+0.02$ & $5+2$ & $0.164+0.016$ & $4.38+0.26$ & $30,553+2510$ \\
\hline UIC 2831 & $136.71 \pm 8.16$ & $3.6 \pm 0.1$ & $8.1 \pm 0.1$ & $2.11 \pm 0.02$ & $5 \pm 2$ & $0.164 \pm 0.016$ & $3.61 \pm 0.21$ & $37,880 \pm 2210$ \\
\hline
\end{tabular}

1. Equivalent dose determined by the multiple aliquot regenerative dose method under blue (470 nm) excitation (Jain et al., 2003). Blue emissions are measured with 3-mm-thick Schott BG-39 and one, 3-mm-thick Corning 7-59 glass filters that blocks $>90 \%$ luminescence emitted below $390 \mathrm{~nm}$ and above $490 \mathrm{~nm}$ in front of the photomultiplier tube. The 4-11 $\mu \mathrm{m}$ quartz fraction for UIC2830 and the 63-100 $\mu \mathrm{m}$ quartz fraction for UIC2831was analyzed.

2. $\mathrm{U}$, Th and $\mathrm{K}_{2} 0$ determined by ICP-MS.

3. Average water content estimated from particle size characteristics assuming periodic wetting in the vadose zone.

4. Cosmic dose rate component from Prescott and Hutton (1994) based on latitude, longitude, elevation, and burial depth of samples.

5. Includes an alpha efficiency value (a value) of $0.05 \pm 0.02$.

6. All errors are at one sigma (68.2\% probability) and ages are calculated from AD 2010. 
Table 4. Frequency occurrence of post-depositional modifications in the Bagratashen 1 lithic assemblage ${ }^{1}$.

\begin{tabular}{|c|c|c|}
\hline Modification (severity score) & $\mathrm{N}$ & $\%$ \\
\hline \multicolumn{3}{|l|}{ Carbonate encrustation } \\
\hline 0 & 19 & 6.5 \\
\hline 1 & 59 & 20.2 \\
\hline 2 & 214 & 73.3 \\
\hline Total & 292 & 100.0 \\
\hline \multicolumn{3}{|l|}{ Weathering/patina } \\
\hline 0 & 13 & 3.6 \\
\hline 1 & 1 & 0.3 \\
\hline 2 & 3 & 0.8 \\
\hline 3 & 342 & 95.3 \\
\hline Total & 359 & 100.0 \\
\hline \multicolumn{3}{|l|}{ Polish } \\
\hline 0 & 389 & 100.0 \\
\hline 1 & 0 & 0.0 \\
\hline 2 & 0 & 0.0 \\
\hline 3 & 0 & 0.0 \\
\hline Total & 389 & 100.0 \\
\hline \multicolumn{3}{|l|}{ Rounding } \\
\hline 0 & 342 & 86.8 \\
\hline 1 & 16 & 4.1 \\
\hline 2 & 34 & 8.6 \\
\hline 3 & 2 & 0.5 \\
\hline Total & 394 & 100.0 \\
\hline
\end{tabular}

1. The number of pieces scored was not the same across modification types.

Table 5. Frequency occurrence of carbonate crust by artifact aspect ${ }^{1}$. \begin{tabular}{|l|l|l|}
\hline Location of crust & $\mathrm{N}$ & $\%$ \\
\hline
\end{tabular} 


\begin{tabular}{|l|l|l|}
\hline None & 19 & 8.6 \\
\hline Side up & 36 & 15.7 \\
\hline Side down & 64 & 27.8 \\
\hline Both sides & 111 & 48.3 \\
\hline Total & 230 & 100.0 \\
\hline
\end{tabular}

1. The null hypothesis that the location of carbonate crusts is distributed equally among the categories can be rejected $\left(\chi^{2}=84.33, \mathrm{df}=3, \mathrm{p}<0.05\right)$.

Table 6. Frequency occurrence of orientations ${ }^{1}$.

\begin{tabular}{|l|c|c|}
\hline Orientation & $\mathrm{N}$ & $\%$ \\
\hline North $\left(337.5^{\circ}-22.5^{\circ}\right)$ & 34 & 9.9 \\
\hline
\end{tabular}




\begin{tabular}{|l|c|c|}
\hline Northeast $\left(22.5^{\circ}-67.5^{\circ}\right)$ & 41 & 11.9 \\
\hline East $\left(67.5^{\circ}-112.5^{\circ}\right)$ & 39 & 11.3 \\
\hline Southeast $\left(112.5^{\circ}-157.5^{\circ}\right)$ & 49 & 14.2 \\
\hline South $\left(157.5^{\circ}-202.5^{\circ}\right)$ & 52 & 15.1 \\
\hline Southwest $\left(202.5^{\circ}-247.5^{\circ}\right)$ & 45 & 13.1 \\
\hline West $\left(247.5^{\circ}-292.5^{\circ}\right)$ & 50 & 14.5 \\
\hline Northwest $\left(292.5^{\circ}-337.5^{\circ}\right)$ & 34 & 9.9 \\
\hline
\end{tabular}

1. The null hypothesis that the frequency of artifacts is distributed equally among the orientation categories cannot be rejected $\left(\chi^{2}=8.82, \mathrm{df}=7, \mathrm{p}=0.32\right)$. 
Table 7. Typological composition of the Bagratashen 1 lithic assemblage ${ }^{1}$.

\begin{tabular}{|c|c|c|c|c|c|c|}
\hline Artifact class & All materials & Complete & Fragment & Retouched & Truncated & Truncated-faceted \\
\hline \multicolumn{7}{|l|}{ Manuports } \\
\hline Complete cobbles/pebbles & 35 & - & - & - & - & - \\
\hline Split cobbles/pebbles & 29 & - & - & - & - & - \\
\hline Possible hammerstones/anvils & 2 & - & - & - & - & - \\
\hline Total & 66 & - & - & - & - & - \\
\hline \multicolumn{7}{|l|}{ Flakes } \\
\hline Points & 21 & 15 & 6 & 8 & 6 & 0 \\
\hline Levallois/prepared & 21 & 7 & 4 & 1 & 0 & 0 \\
\hline Blades & 6 & 4 & 2 & 0 & 0 & 0 \\
\hline Unspecified & 209 & 42 & 123 & 14 & 22 & 11 \\
\hline Platform truncation & 25 & 25 & 0 & 0 & 0 & 0 \\
\hline Core on flake & 4 & - & - & - & - & - \\
\hline Total & 277 & 93 & 136 & 23 & 28 & 11 \\
\hline Core elements & 55 & - & - & - & - & - \\
\hline \multicolumn{7}{|l|}{ Cores } \\
\hline Initial & 5 & 5 & 0 & - & - & - \\
\hline Parallel-unidirectional & 5 & 5 & 0 & - & - & - \\
\hline Parallel-bidirectional & 2 & 2 & 0 & - & - & - \\
\hline Parallel-multidirectional & 3 & 3 & 0 & - & - & - \\
\hline Parallel-unspecified & 8 & 5 & 3 & - & - & - \\
\hline Inclined-centripetal & 1 & 1 & 0 & - & - & - \\
\hline Inclined-noncentripetal & 4 & 4 & 0 & - & - & - \\
\hline Irregular & 10 & 9 & 1 & - & - & - \\
\hline Total & 38 & 34 & 4 & - & - & - \\
\hline Indeterminate & 64 & - & - & - & - & - \\
\hline Total & 500 & & & & & \\
\hline
\end{tabular}

1. Truncated pieces are not considered to be fragments.

Table 8. Metric and non-metric attributes of the Bagratashen 1 points ${ }^{1,2,3,4}$.

\begin{tabular}{|c|c|c|c|c|c|c|c|c|c|c|c|}
\hline $\begin{array}{l}\text { Catalogue } \\
\text { number }\end{array}$ & Description & $\begin{array}{l}\text { Maximum } \\
\text { length }\end{array}$ & $\begin{array}{l}\text { Maximum } \\
\text { width }\end{array}$ & $\begin{array}{l}\text { Midpoint } \\
\text { width }\end{array}$ & $\begin{array}{l}\text { Maximum } \\
\text { thickness }\end{array}$ & $\begin{array}{c}\text { Tip } \\
\text { angle }\end{array}$ & TCSA & TCSP & Platform & Retouch & $\begin{array}{c}\text { Basal } \\
\text { modification }\end{array}$ \\
\hline
\end{tabular}




\begin{tabular}{|c|c|c|c|c|c|c|c|c|c|c|c|}
\hline & & $(\mathrm{mm})$ & $(\mathrm{mm})$ & $(\mathrm{mm})$ & $(\mathrm{mm})$ & & & & & & \\
\hline 413 & Levallois point & - & 41.33 & 13.9 & 5.04 & - & 36.11 & 31.85 & US & None & None \\
\hline 771 & Retouched point & 76.63 & 23.23 & 21.36 & 10.43 & 31 & 121.14 & 54.45 & Plain & Stepped & US \\
\hline 898 & Levallois point & & 30.72 & - & 4.84 & - & 74.34 & 62.93 & Faceted & None & None \\
\hline 2009-10TE & $\begin{array}{l}\text { Elongated retouched } \\
\text { Levallois/Mousterian } \\
\text { point }\end{array}$ & 86.68 & 36.2 & 35.13 & 11.01 & - & 199.28 & 78.57 & Faceted & Scaled & None \\
\hline $799+1013$ & $\begin{array}{l}\text { Retouched Levallois } \\
\text { point }\end{array}$ & 59.4 & 34.51 & 26.29 & 5.44 & 52 & 93.87 & 70.69 & Faceted & Stepped & None \\
\hline 572 & $\begin{array}{l}\text { Elongated Levallois } \\
\text { point }\end{array}$ & 116.06 & 48.19 & 44.37 & 17.64 & 42 & 425.04 & 107.91 & Faceted & None & None \\
\hline 197 & Levallois point & 47.94 & 23.55 & 21.77 & 6.18 & - & 72.77 & 50.15 & Cortical & None & None \\
\hline 842 & Levallois point & 41.62 & 16.35 & 15.28 & 5.72 & 57 & 46.76 & 36.30 & Truncated & None & Truncated \\
\hline 922 & Levallois point & & 26.51 & 24.93 & 5.2 & - & 68.93 & 54.99 & Truncated & None & Thinned \\
\hline 381 & Levallois point & 32.5 & 17.18 & 14.59 & 5.05 & - & 43.38 & 37.11 & Truncated & None & Thinned \\
\hline 701 & $\begin{array}{l}\text { Retouched Levallois } \\
\text { point }\end{array}$ & 71.64 & 26.76 & 23.76 & 9.62 & 33 & 128.72 & 59.72 & US & Scaled & Thinned \\
\hline 1418 & $\begin{array}{l}\text { Elongated retouched } \\
\text { Levallois point }\end{array}$ & 87.46 & 38.72 & 23.63 & 8.62 & 32 & 166.88 & 81.10 & Faceted & Scaled & Thinned \\
\hline 484 & Levallois point & - & 18.42 & - & 6.52 & - & 60.05 & 40.99 & Truncated & US & Thinned \\
\hline 410.4 & Levallois point & 31.99 & 22.68 & 22.29 & 8.96 & 66 & 101.61 & 51.59 & Truncated & None & Thinned \\
\hline 279 & Levallois point & 29.42 & 33.74 & 25.81 & 6.24 & 90 & 105.27 & 69.71 & US & None & Thinned \\
\hline 1371 & Levallois point & 30.49 & 17.81 & 16.57 & 6.88 & 67 & 61.27 & 40.32 & Truncated & Scaled & Truncated \\
\hline 459 & Retouched point & 82.73 & 26.69 & 25.01 & 11.56 & 45 & 154.27 & 62.00 & Truncated & Stepped & Truncated \\
\hline $2009-47$ & Levallois point & 71.16 & 44.84 & 35.64 & 7.81 & - & 175.10 & 92.32 & Truncated & None & Truncated \\
\hline $2009-45$ & Levallois point & 60.49 & 33.60 & 31.31 & 13.33 & 61 & 223.94 & 76.49 & Truncated & None & Thinned \\
\hline $2009-43$ & Levallois point & 50.49 & 17.6 & 17.48 & 6.43 & 51 & 56.58 & 39.40 & US & None & None \\
\hline
\end{tabular}

1. Specimens 2009-47, 2009-45, and 2009-43 are surface finds and are not included in the Table 7 counts.

2. $\mathrm{TCSA}=(0.5 *$ maximum width $) *$ maximum thickness (after Hughes, 1998: 354).

3. TCSP $=$ maximum width $+2 * \sqrt{ }\left((0.5 * \text { maximum width })^{2}+\left(\right.\right.$ maximum thickness $\left.\left.{ }^{2}\right)\right)($ after Sisk and Shea, 2009: 2043).

4. US = unspecified.

Table 9. Metric attributes for complete blanks in the Bagratashen 1 lithic assemblage ${ }^{1}$.

\begin{tabular}{|l|l|l|l|l|l|}
\hline Catalog number & Length $(\mathrm{mm})$ & Maximum width $(\mathrm{mm})$ & Midpoint thickness $(\mathrm{mm})$ & Length:Width & Width:Thickness \\
\hline 654 & 54.63 & 45.37 & 9.80 & 1.20 & 4.63
\end{tabular}




\begin{tabular}{|c|c|c|c|c|c|}
\hline 744 & 69.6 & 56.71 & 15.74 & 1.23 & 3.60 \\
\hline 593 & 29.55 & 21.24 & 7.09 & 1.39 & 3.00 \\
\hline 687 & 43.32 & 19.60 & 5.06 & 2.47 & 3.87 \\
\hline 733 & 66.34 & 43.76 & 13.54 & 1.52 & 3.23 \\
\hline 718 & 60.81 & 15.63 & 5.21 & 3.89 & 3.00 \\
\hline 194 & 47.43 & 17.45 & 6.44 & 2.72 & 2.71 \\
\hline 377 & 44.11 & 32.16 & 7.05 & 1.37 & 4.56 \\
\hline 402 & 67.09 & 40.16 & 8.74 & 1.67 & 4.59 \\
\hline 557 & 51.86 & 27.9 & 7.49 & 1.86 & 3.72 \\
\hline 197 & 46.85 & 23.03 & 5.20 & 2.03 & 4.43 \\
\hline 478 & 37.72 & 26.53 & 4.97 & 1.42 & 5.34 \\
\hline 1469 & 30.34 & 39.08 & 6.20 & 0.78 & 6.30 \\
\hline 1539 & 26.73 & 16.78 & 4.15 & 1.59 & 4.04 \\
\hline 1139 & 52.17 & 19.54 & 4.90 & 2.67 & 3.99 \\
\hline 1410 & 45.23 & 30.95 & 4.52 & 1.46 & 6.85 \\
\hline 285 & 33.71 & 27.42 & 5.14 & 1.23 & 5.33 \\
\hline 364 & 37.64 & 31.08 & 7.93 & 1.21 & 3.92 \\
\hline 262 & 36.66 & 32.63 & 5.42 & 1.12 & 6.02 \\
\hline 419 & 30.09 & 22.87 & 2.98 & 1.32 & 7.67 \\
\hline 1378 & 42.73 & 35.73 & 12.14 & 1.20 & 2.94 \\
\hline 672 & 59.38 & 39.47 & 8.98 & 1.50 & 4.40 \\
\hline 569 & 36.95 & 36.87 & 6.61 & 1.00 & 5.58 \\
\hline 797 & 73.45 & 39.06 & 6.57 & 1.88 & 5.95 \\
\hline 1337 & 42.48 & 24.91 & 5.31 & 1.71 & 4.69 \\
\hline 2009-7TE & 44.48 & 40.88 & 5.74 & 1.09 & 7.12 \\
\hline 413 & 22.47 & 13.94 & 4.88 & 1.61 & 2.86 \\
\hline 572 & 114.62 & 45.91 & 14.57 & 2.50 & 3.15 \\
\hline Mean & 48.33 & 30.95 & 7.23 & 1.67 & 4.55 \\
\hline S.D. & 3.54 & 2.05 & 0.61 & 0.13 & 0.26 \\
\hline
\end{tabular}

1. See Table 1 for descriptions of measurements. 
Table 10. Chronometric dates for Middle Paleolithic sites in the southern Caucasus ${ }^{1,2,3}$.

\begin{tabular}{|l|l|l|l|l|l|}
\hline Site & Site Type & Layer/Unit & Date (uncalibrated BP) & Date (calendar) & Reference \\
\hline Hovk 1 (Armenia) & Cave & 8 & & $104,000 \pm 9,800 \mathrm{BP}_{\mathrm{OSL}}$ & Pinhasi et al. (2008: Table 1) \\
\hline Drjuchula (Georgia) & Cave & 1 & & $140,000 \pm 13,000 \mathrm{BP}_{\mathrm{TL}}$ & Mercier et al. (2010: Table 1) \\
\hline & & 1 & & $138,000 \pm 15,000 \mathrm{BP}$ TL & Mercier et al. (2010: Table 1) \\
\hline & & 2 & & $227,000 \pm 30,000 \mathrm{BP} \mathrm{TL}_{\mathrm{TL}}$ & Mercier et al. (2010: Table 1) \\
\hline & & 2 & & $210,000 \pm 34,000 \mathrm{BP}$ & Mercier et al. (2010: Table 1) \\
\hline & & 2 & $259,000 \pm 26,000 \mathrm{BP}$ & Mercier et al. (2010: Table 1) \\
\hline & & 2 & $243,000 \pm 26,000 \mathrm{BP}$ & Mercier et al. (2010: Table 1) \\
\hline Azokh 1 (Nagorno-Karabagh) & Cave & 2 Upper & & $100,000 \pm 7,000 \mathrm{BP}$ ESR & Asryan et al. (2014: 37) \\
\hline & & 2 Lower & & $184,000 \pm 13,000 \mathrm{BP}_{\mathrm{ESR}}$ & Asryan et al. (2014: 37) \\
\hline
\end{tabular}




\begin{tabular}{|c|c|c|c|c|c|}
\hline Kudaro 1 (Georgia) & Cave & 3 & $44,150 \pm 2400 / 1850(\mathrm{GrN} 6079)$ & & Liubin (1971: 12) \\
\hline \multirow[t]{3}{*}{ Kudaro 3 (Georgia) } & Cave & 3 & & $80,000 \mathrm{BP}_{\mathrm{U}-\mathrm{Th}}$ & $\begin{array}{l}\text { Golovanova and Doronichev } \\
\text { (2003: 78) }\end{array}$ \\
\hline & & 4 & & $110,000 \pm 10,000 \mathrm{BP}_{\mathrm{U}-\mathrm{Th}}$ & $\begin{array}{l}\text { Golovanova and Doronichev } \\
(2003: 78)\end{array}$ \\
\hline & & & & $96,000 \pm 10,000 \mathrm{BP}_{\mathrm{RTL}}$ & $\begin{array}{l}\text { Golovanova and Doronichev } \\
\text { (2005: 14) }\end{array}$ \\
\hline Tsona (Georgia) & Cave & 5 & & $46,000 \pm 4,000 \mathrm{BP}_{\mathrm{U}-\mathrm{Th}}$ & Liubin $(2002: 91)$ \\
\hline \multirow[t]{4}{*}{ Kalavan 2 (Armenia) } & Open-air & $6 / 7$ & $16,740 \pm 130($ UGAMS-2296) & $20,204 \pm 171 \mathrm{Cal} \mathrm{BP}$ & $\begin{array}{l}\text { Cherinsky and Chataigner (2010: } \\
\text { Table 1); Ghukasyan et al. } \\
\text { (2011: Table 3) }\end{array}$ \\
\hline & & & $20,020 \pm 100($ UGAMS-2296) & $24,085 \pm 139 \mathrm{Cal} \mathrm{BP}$ & $\begin{array}{l}\text { Cherinsky and Chataigner (2010: } \\
\text { Table 1); Ghukasyan et al. } \\
\text { (2011: Table 3) }\end{array}$ \\
\hline & & 7 & $34,200 \pm 360($ Poz-20366) & $38,739 \pm 392 \mathrm{Cal} \mathrm{BP}$ & Ghukasyan et al. (2011: Table 3) \\
\hline & & $7 ?$ & $27,000 \pm 400(\mathrm{Poz}-22181)$ & $31,055 \pm 250$ Cal BP & Ghukasyan et al. (2011: Table 3) \\
\hline \multirow[t]{4}{*}{ Lusakert 1 (Armenia) } & Rockshelter & $\mathrm{C}$ & $\begin{array}{l}26,920 \pm 220(\text { GRA 14949/Lyon } \\
1006)\end{array}$ & $31,015 \pm 135 \mathrm{Cal} \mathrm{BP}$ & Fourboubey et al. (2003: 13) \\
\hline & & & & $36,600 \pm 2,800 \mathrm{BP}_{\mathrm{OSL}}$ & Adler et al. (2012: 27) \\
\hline & & & & $35,300 \pm 2,800 \mathrm{BP}_{\mathrm{OSL}}$ & Adler et al. (2012: 27) \\
\hline & & & & $23,900 \pm 1,900 \mathrm{BP}_{\mathrm{OSL}}$ & Adler et al. (2012: 27) \\
\hline \multirow[t]{6}{*}{ Yerevan 1 (Armenia) } & Cave & 3 & $32,600 \pm 800(\mathrm{GrN} \mathrm{8028a})$ & $36,800 \pm 1,022 \mathrm{Cal} \mathrm{BP}$ & Pinhasi et al. (2008: Table 3) \\
\hline & & & $31,600 \pm 800($ GrN 8028b $)$ & $35,538 \pm 846 \mathrm{Cal} \mathrm{BP}$ & Pinhasi et al. (2008: Table 3) \\
\hline & & 4 & $>47,800(\mathrm{GrN} 7665)$ & & Pinhasi et al. (2008: Table 3) \\
\hline & & & $>49,000(\mathrm{GrN} 7665)$ & & Pinhasi et al. (2008: Table 3) \\
\hline & & 7 & $27,000 \pm 650(\mathrm{GrN} 8860)$ & $31,058 \pm 613 \mathrm{Cal} \mathrm{BP}$ & Pinhasi et al. (2008: Table 3) \\
\hline & & & $28,000 \pm 500(\mathrm{GrN} 8860)$ & $31,922+586 \mathrm{Cal} \mathrm{BP}$ & Pinhasi et al. (2008: Table 3) \\
\hline \multirow[t]{6}{*}{ Sakajia (Georgia) } & Cave & $3 \mathrm{a}$ & $34,700 \pm 900(\mathrm{OxA} X-2352-45)$ & $39,364 \pm 1,016 \mathrm{Cal} \mathrm{BP}$ & Pinhasi et al. (2012: Table 1) \\
\hline & & & $35,100 \pm 600(\mathrm{OxA} 22,112)$ & $39,634 \pm 668 \mathrm{Cal} \mathrm{BP}$ & Pinhasi et al. (2012: Table 1) \\
\hline & & $3 \mathrm{~b}$ & $40,200 \pm 1200(\mathrm{OxA} 22,130)$ & $43,911 \pm 998 \mathrm{Cal} \mathrm{BP}$ & Pinhasi et al. (2012: Table 1) \\
\hline & & & $43,800 \pm 3200(\mathrm{OxA} X-2352-46)$ & $>45,000 \mathrm{Cal} \mathrm{BP}$ & Pinhasi et al. (2012: Table 1) \\
\hline & & & $45,600 \pm 2300(\mathrm{OxA} 22,131)$ & $>47,000 \mathrm{Cal} \mathrm{BP}$ & Pinhasi et al. (2012: Table 1) \\
\hline & & $3 \mathrm{c}$ & $>45,700(\mathrm{OxA} 22,132)$ & & Pinhasi et al. (2012: Table 1) \\
\hline \multirow[t]{2}{*}{ Ortvala (Georgia) } & Cave & 3 & $38,500 \pm 1000(\mathrm{OxA} 22,133)$ & $42,610 \pm 751 \mathrm{Cal} \mathrm{BP}$ & Pinhasi et al. (2012: Table 2) \\
\hline & & & $>41,100(\mathrm{OxA} X-2352-47)$ & & Pinhasi et al. (2012: Table 2) \\
\hline \multirow[t]{3}{*}{ Bronze (Georgia) } & Cave & MP1 & $>44,100(\mathrm{OxA} X-2352-44)$ & & Pinhasi et al. (2012: Table 3) \\
\hline & & & $36,700 \pm 800($ RTT 4222) & $41,256 \pm 697 \mathrm{Cal} \mathrm{BP}$ & Adler et al. (2008: Table 10) \\
\hline & & & $22,900 \pm 200($ RTT 4223$)$ & $27,254 \pm 197 \mathrm{Cal} \mathrm{BP}$ & Adler et al. (2008: Table 10) \\
\hline
\end{tabular}




\begin{tabular}{|c|c|c|c|c|c|}
\hline & & & $>45,000$ (RTT 4229) & & Adler et al. (2008: Table 10) \\
\hline & & & $29,700 \pm 360($ RTT 4221) & $33,856 \pm 309 \mathrm{Cal} \mathrm{BP}$ & Adler et al. (2008: Table 10) \\
\hline & & & $34,500 \pm 600($ RTT 4224) & $39,092+657 \mathrm{Cal} \mathrm{BP}$ & Adler et al. (2008: Table 10) \\
\hline & & & $39,500 \pm 1200($ RTT 4225$)$ & $43,421 \pm 965 \mathrm{Cal} \mathrm{BP}$ & Adler et al. (2008: Table 10) \\
\hline & & MP2 & $>48,500($ OxA 22,107$)$ & & Pinhasi et al. (2012: Table 3) \\
\hline & & & $46,300 \pm 2600(\mathrm{RTT} 4226)$ & $>47,000 \mathrm{Cal} \mathrm{BP}$ & Adler et al. (2008: Table 10) \\
\hline & & & $41,600 \pm 1400($ RTT 4227) & $>43,000 \mathrm{Cal} \mathrm{BP}$ & Adler et al. (2008: Table 10) \\
\hline & & & $>45,000($ RTT 4228) & & Adler et al. (2008: Table 10) \\
\hline & & MP 3 & $>45,000($ RTT 4230) & & Adler et al. (2008: Table 10) \\
\hline & & & $43,500 \pm 2000(\mathrm{RTT} 4231)$ & $>45,000 \mathrm{Cal} \mathrm{BP}$ & Adler et al. (2008: Table 10) \\
\hline & & & $34,200 \pm 1200($ RTT 4231) & $38,594 \pm 1,462 \mathrm{Cal} \mathrm{BP}$ & Adler et al. (2008: Table 10) \\
\hline & & MP4 & $>50,000($ OxA 22,108$)$ & & Pinhasi et al. (2012: Table 3) \\
\hline & & MP5 & $>50,000($ OxA 22,109) & & Pinhasi et al. (2012: Table 3) \\
\hline \multirow[t]{8}{*}{ Ortvale Klde (Georgia) } & Cave & 5 & & $45,785 \pm 2,198 \mathrm{BP}_{\mathrm{TL}}$ & Adler et al. (2008: Table 3) \\
\hline & & & $\begin{array}{l}38,500 \pm 768 \text { (RTT 3826a, } \\
3826 \mathrm{~b})\end{array}$ & $40,620 \pm 538 \mathrm{Cal} \mathrm{BP}$ & Adler et al. (2008: Table 8) \\
\hline & & 6 & & $48,538 \pm 2,286 \mathrm{BP}_{\mathrm{TL}}$ & Adler et al. (2008: Table 3) \\
\hline & & & $\begin{array}{l}42,764 \pm 806 \text { (RTT 4216, 3961, } \\
4217,4219,3962 ; \text { AA 45866) }\end{array}$ & $46,052 \pm 788 \mathrm{Cal} \mathrm{BP}$ & Adler et al. (2008: Table 8) \\
\hline & & 7 & & $43,289 \pm 1,593 \mathrm{BP}_{\mathrm{TL}}$ & Adler et al. (2008: Table 3) \\
\hline & & & & $44,491 \pm 1,792 \mathrm{BP}_{\mathrm{ESR}} \mathrm{EU}$ & Adler et al. (2008: Table 6) \\
\hline & & & & $47,877 \pm 2,060 \mathrm{BP}_{\mathrm{ESR}} \mathrm{LU}$ & Adler et al. (2008: Table 6) \\
\hline & & & $43,000 \pm 1150($ RTT 3430) & $>45,000 \mathrm{Cal} \mathrm{BP}$ & Adler et al. (2008: Table 8) \\
\hline \multirow[t]{2}{*}{ Bondi (Georgia) } & Cave & 7 & $35,070 \pm 340($ Beta 2392227$)$ & $39,609 \pm 416 \mathrm{Cal} \mathrm{BP}$ & $\begin{array}{l}\text { Tushabramishvili et al. (2012: } \\
\text { Table 1) }\end{array}$ \\
\hline & & & $38,750 \pm 480($ Beta 270162$)$ & $42,702 \pm 330 \mathrm{Cal} \mathrm{BP}$ & $\begin{array}{l}\text { Tushabramishvili et al. (2012: } \\
\text { Table 1) }\end{array}$ \\
\hline
\end{tabular}

1. All ${ }^{14} \mathrm{C}$ dates are calibrated using OxCal v. 4.2 .4 (c14.arch.ox.ac.uk) and the IntCal 13 atmospheric curve (Reimer et al., 2013).

2. All ranges reflect one-sigma $(68.2 \%)$ probabilities.

3. Dates from Ortvale Klde represent weighted means (Adler et al., 2008). 
Table 11. Technological indices for southern Caucasian sites and the three main Levantine MP facies ${ }^{1,2,3,4,5}$.

\begin{tabular}{|l|l|l|l|l|}
\hline Assemblage/facies & Laminar index & Levallois index & Faceting index & Strict faceting index \\
\hline Bagratashen 1 & 24.1 & 9.4 & 44.8 & 39.1 \\
\hline Djurchula Layer 1 & 68.5 & 60.4 & 62.5 & 30.0 \\
\hline Djurchula Layer 2 & 41.2 & 36.3 & 38.8 & 18.8 \\
\hline Tsona & 64.2 & 64.2 & - & - \\
\hline Kudaro 1 & 74.4 & 62.2 & 67.7 & 37.2 \\
\hline Kudaro 3 & 28.8 & 55.5 & 60.0 & 39.3 \\
\hline Southern Caucasian mean & 55.4 & 55.7 & 57.3 & 31.3 \\
\hline Southern Caucasian 95\% CI & $38.3-72.5^{*}$ & $45.8-65.6^{*}$ & $46.2-68.4^{*}$ & $23.1-39.5$ \\
\hline Tabūn Type-B mean (n =19) & 22.5 & 26.9 & 61.9 & 50.4 \\
\hline
\end{tabular}




\begin{tabular}{|l|l|l|l|l|}
\hline Tabūn Type-B 95\% CI & $15.6-29.4$ & $17.5-36.3^{*}$ & $54.2-69.6^{*}$ & $41.4^{-59.4 *}$ \\
\hline Tabūn Type-C mean $(\mathrm{n}=21)$ & 14.2 & 36.7 & 63.5 & 51.6 \\
\hline Tabūn Type-C 95\% CI & $10.6-17.8^{*}$ & $27.1-46.3^{*}$ & $58.0-68.9^{*}$ & $46.5^{*}-56.7^{*}$ \\
\hline Tabūn Type-D mean $(\mathrm{n}=12)$ & 37.6 & 39.4 & 60.6 & 43.1 \\
\hline Tabūn Type-D 95\% CI & $26.9-48.3^{*}$ & $24.4-54.4^{*}$ & $56.5-64.7^{*}$ & $37.2-49.0$ \\
\hline
\end{tabular}

1. Tsona, Kudaro 1, and Kudaro 3 data from Liubin (1977: 191).

2. Although index values for Djurchula also appear in Liubin (1977: 191), they differ from those reported by him in 1989 (Liubin, 1989: 57-58). We present the later, and presumably more accurate, data here.

3. $95 \%$ confidence intervals for Levantine sites calculated from raw data in Culley et al. (2013: Table 14).

4. Southern Caucasian mean excludes Bagratashen 1 values.

5. An $(*)$ indicates that the Bagratashen 1 values fall outside the $95 \%$ confidence interval of the comparative datasets. 


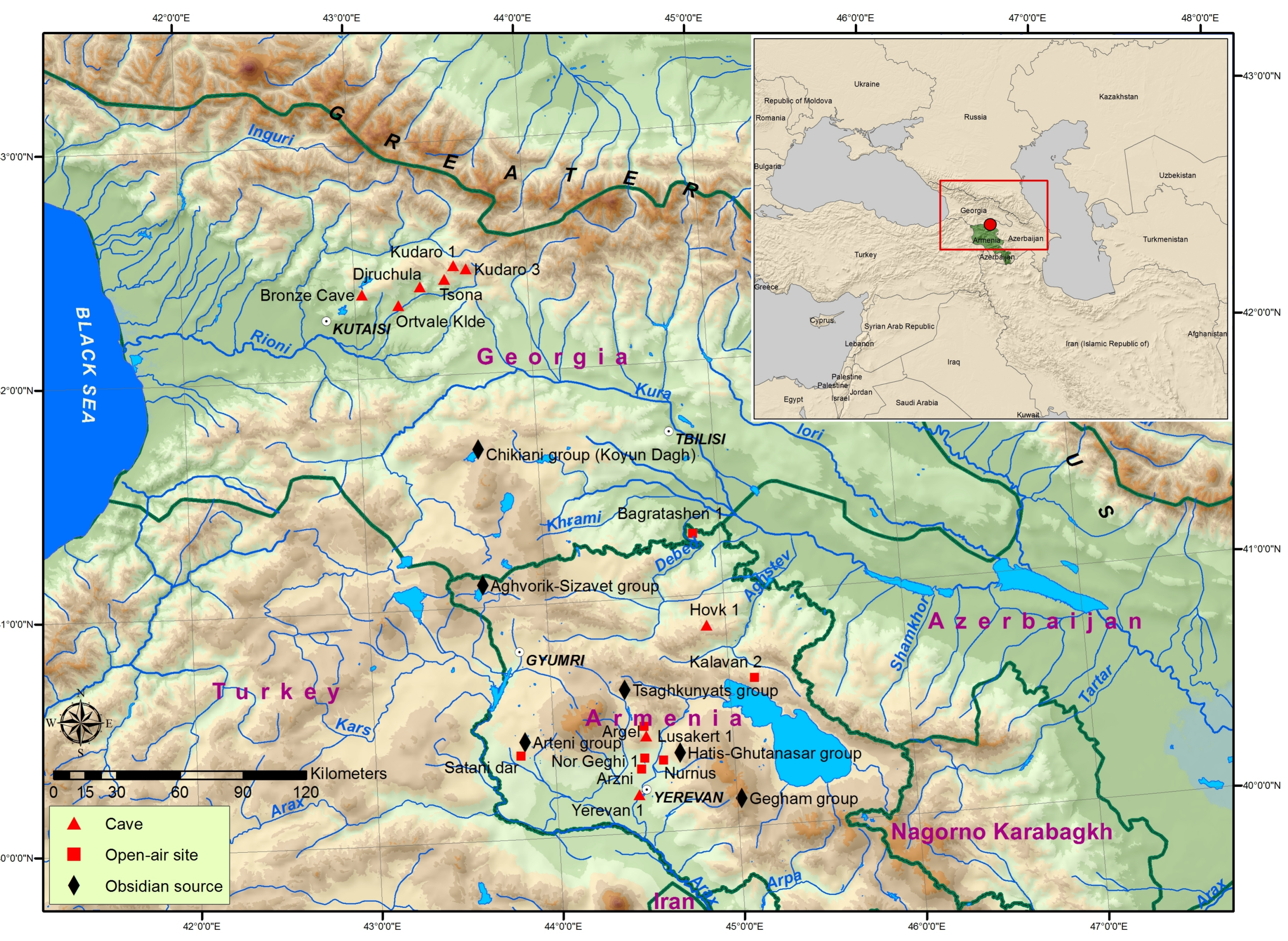




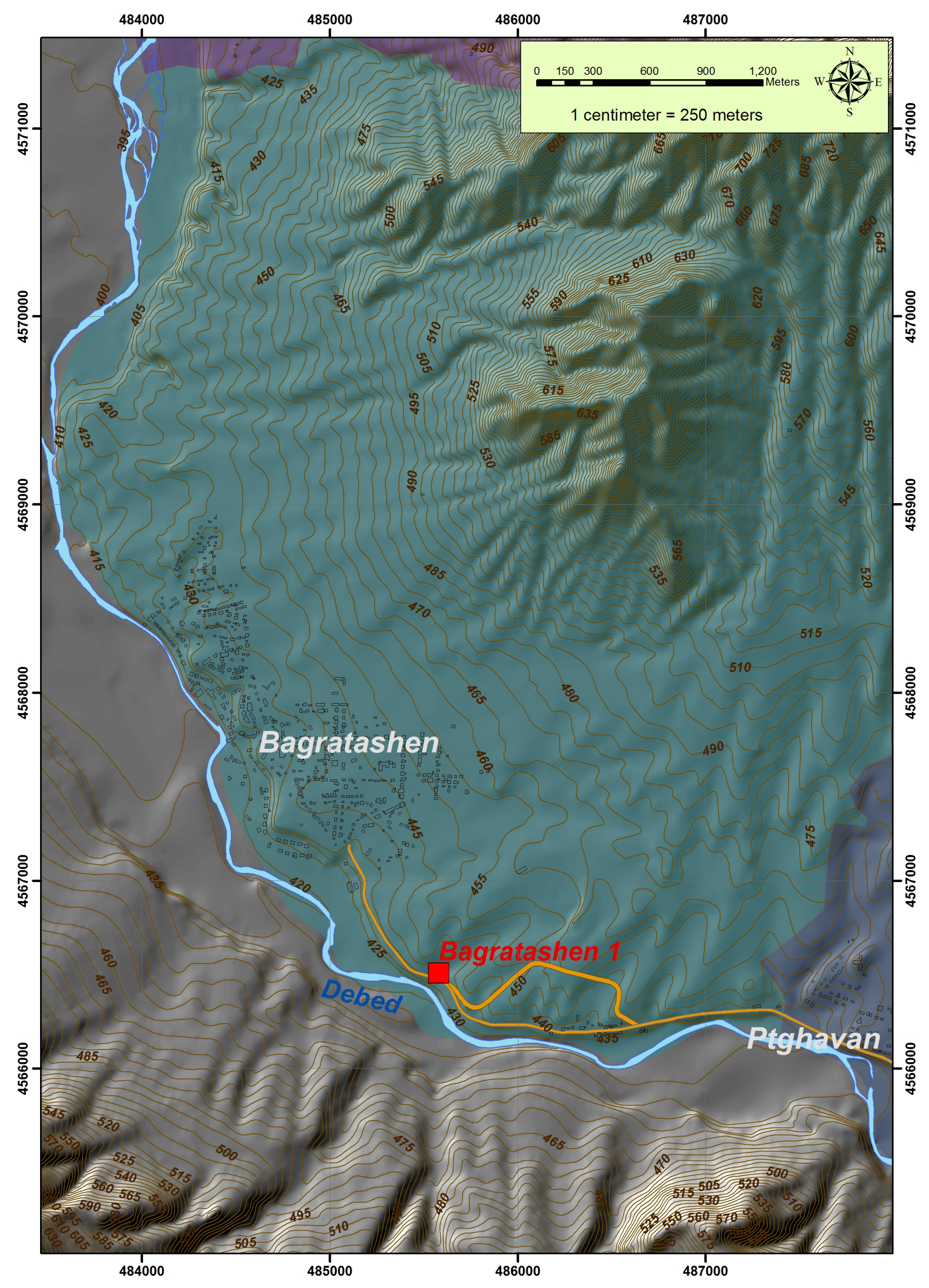


Archaeological horizon

1 (Modern/Medieval)

2 (Chalcolithic/Upper Paleolithic)

3a (Middle Paleolithic)

3b (Middle Paleolithic)

\begin{tabular}{ccc} 
Geological horizon & Color & Texture \\
\hline $1(\mathrm{Ap})$ & 2.5 Y $4 / 3$ & Silt loam \\
\hline $2(\mathrm{~B})$ & 2.5 Y $5 / 2$ & Silty clay loam \\
\hline $3(\mathrm{C})$ & 2.5 Y $5 / 2$ & Silty clay loam \\
\hline $4(2 \mathrm{~A})$ & 2.5 Y $4 / 2$ & Silty clay loam \\
\hline $5(2 \mathrm{~B})$ & $2.5 Y 5 / 4$ & Silt loam \\
& & \\
\hline $6\left(2 \mathrm{~B}_{2}\right)$ & $2.5 Y 5 / 4$ & Silt loam \\
& & \\
\hline $7(2 \mathrm{C})$ & & Silt loam
\end{tabular}

$8(3 B) \quad 2.5 Y R 5 / 4 \quad$ Silty clay loam




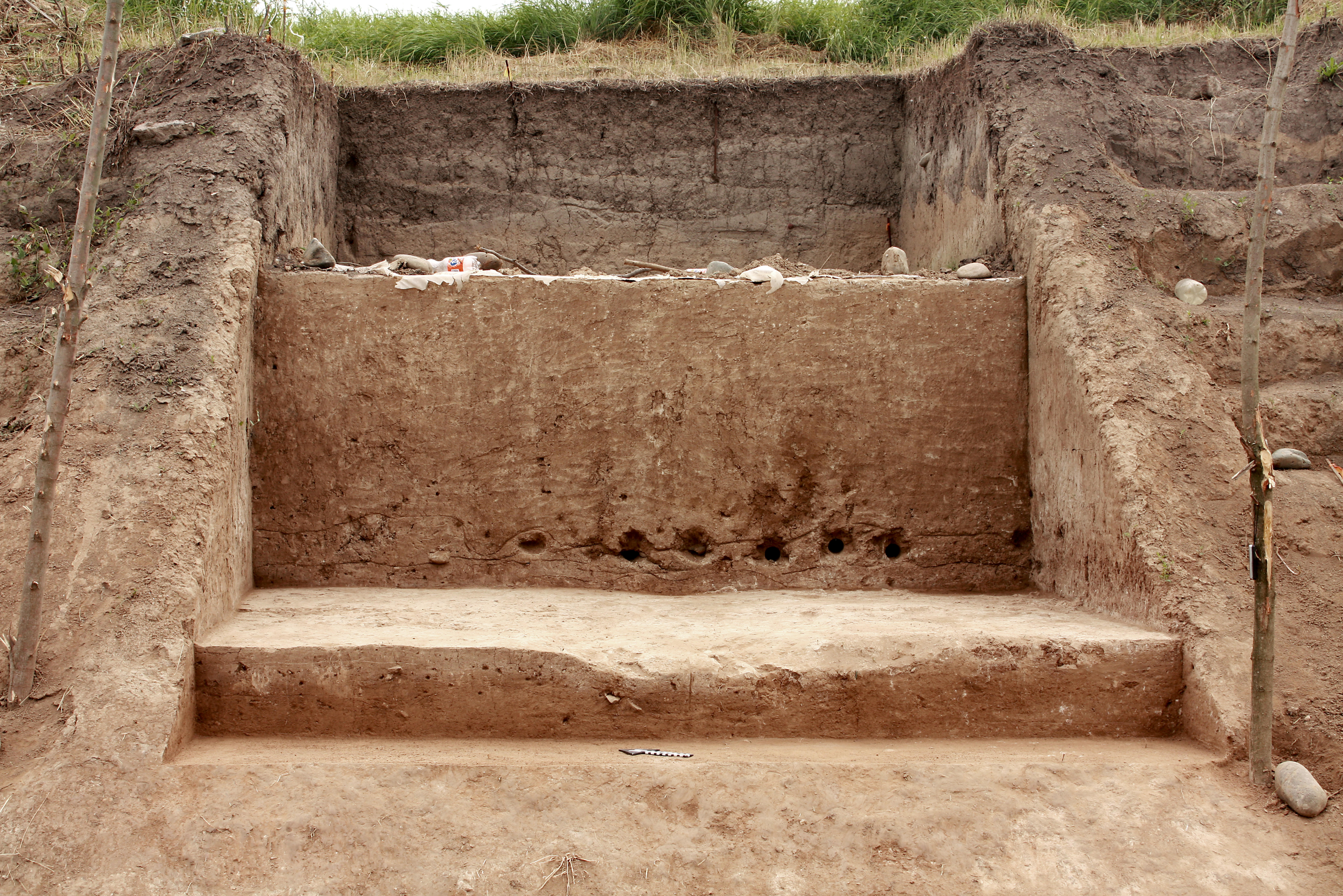




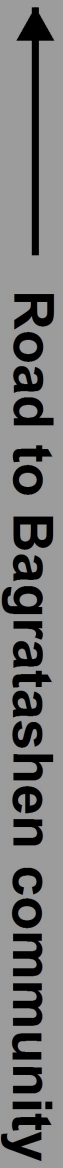

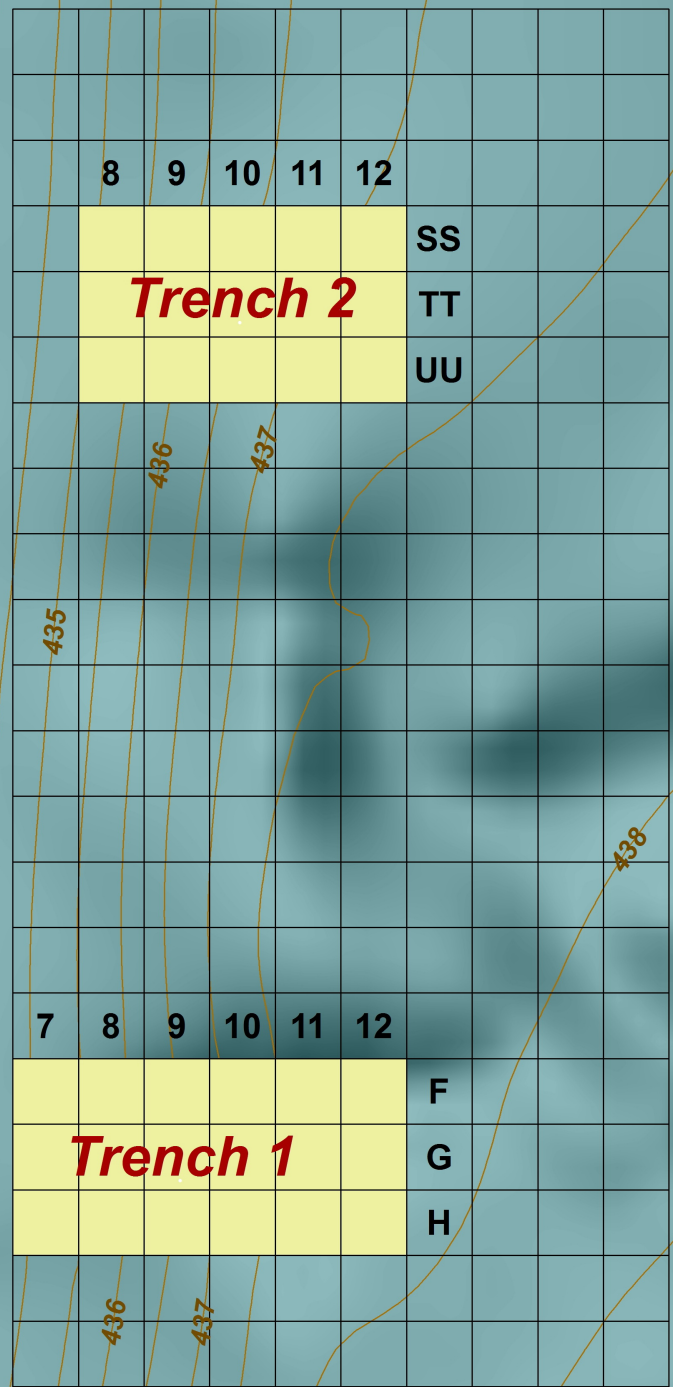

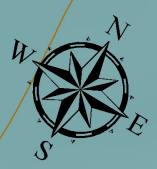




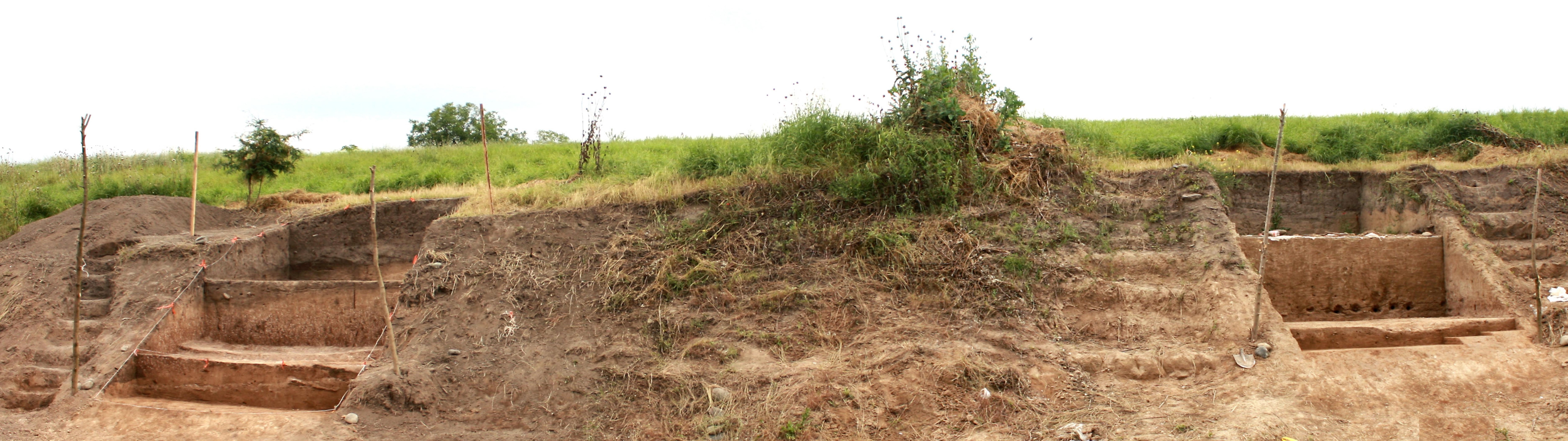




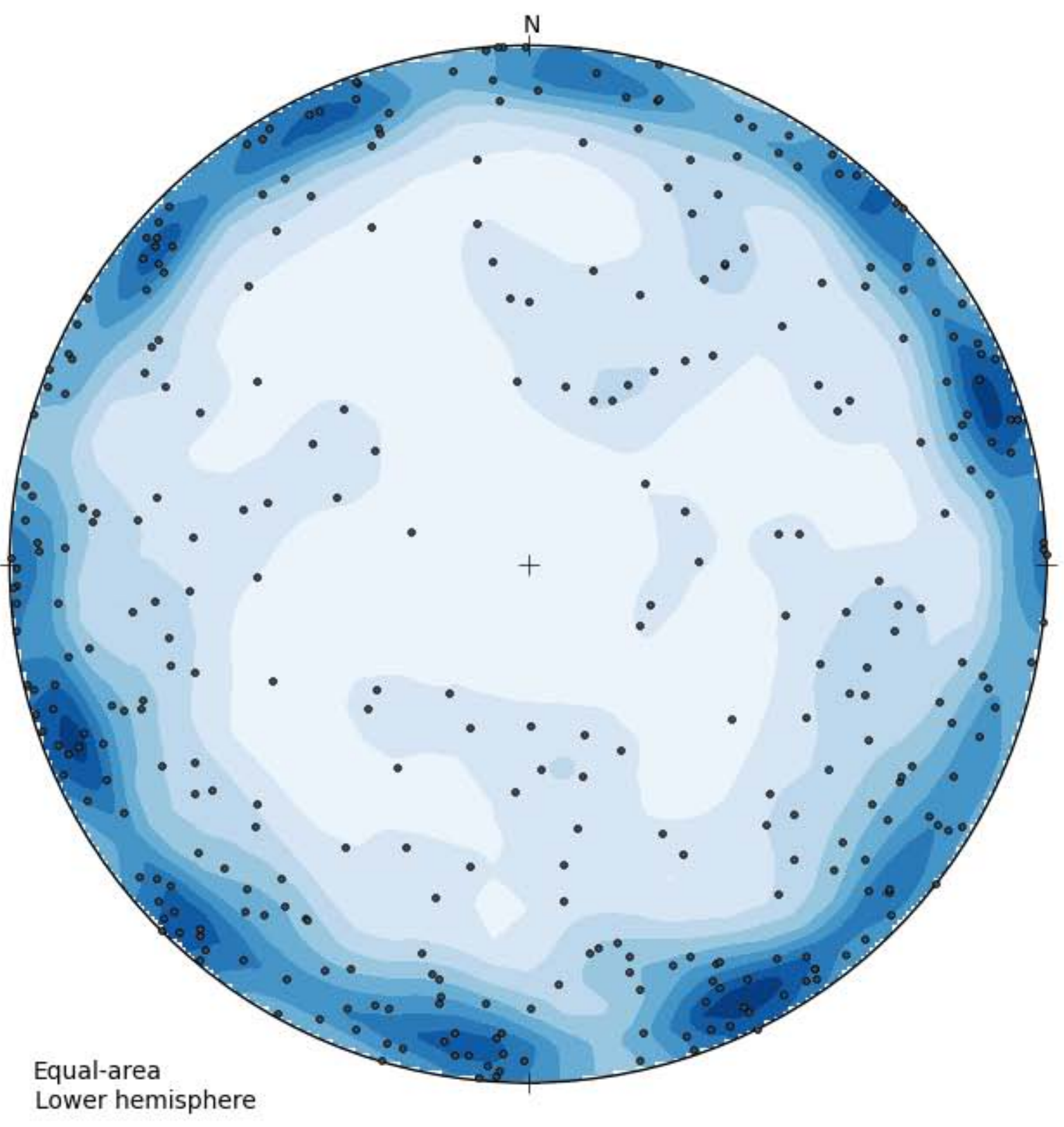

Density

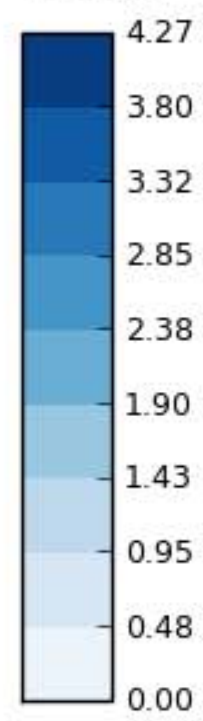

Lineations

Maximum density: $4.3 \%$ at $154.3 / 7.4$

Grid detail: Low

Counting method:

Fisher Distribution 


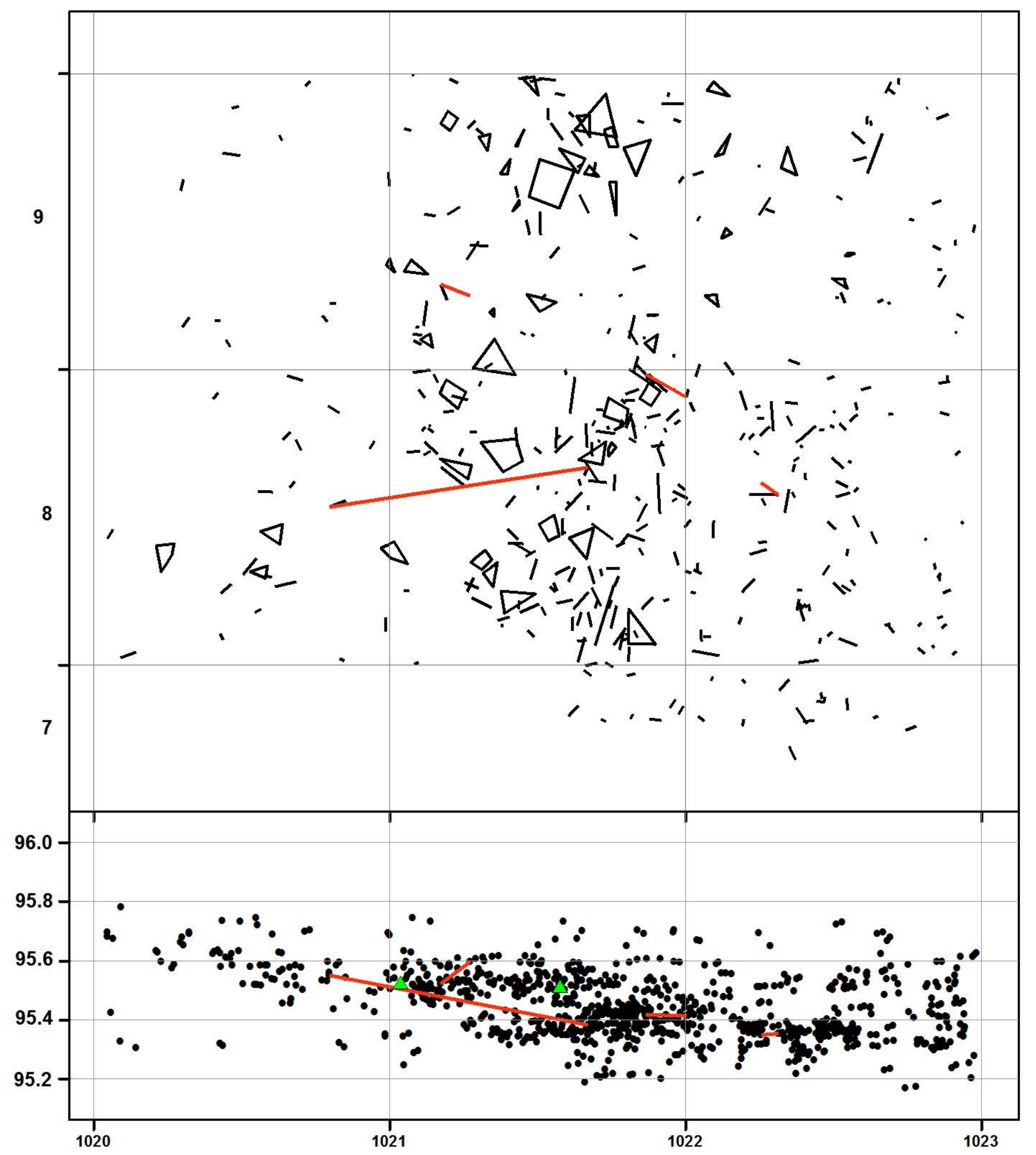




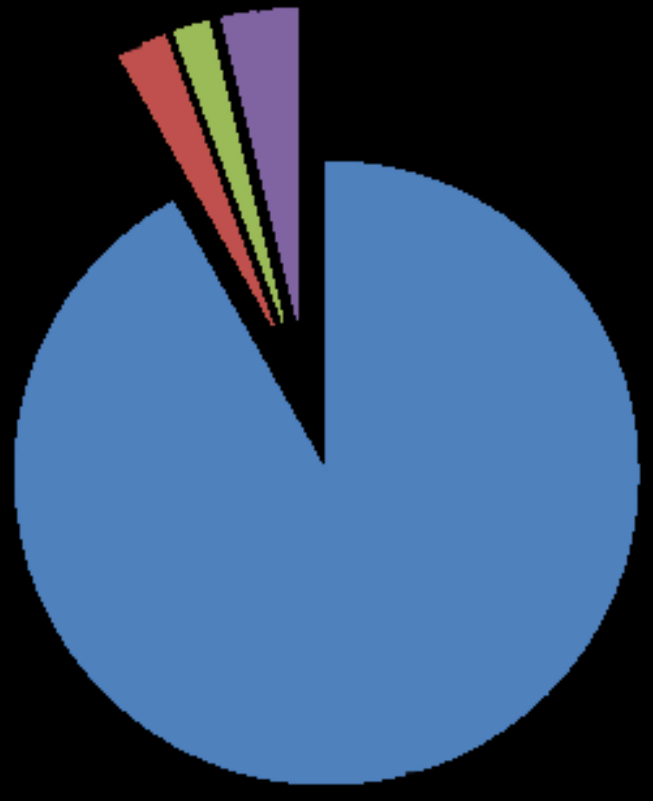


(

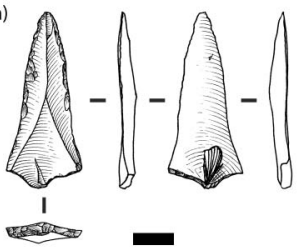

(b)

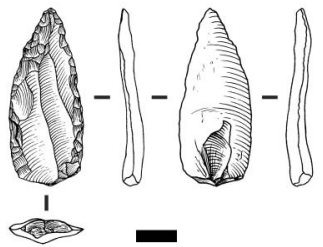

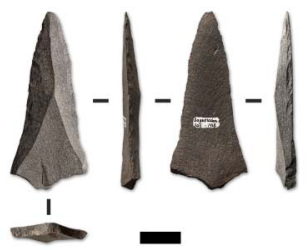

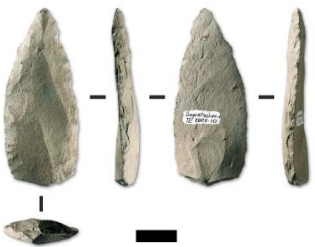




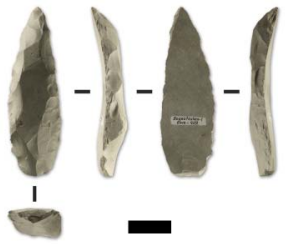

(a)

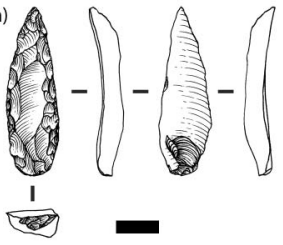

(b)

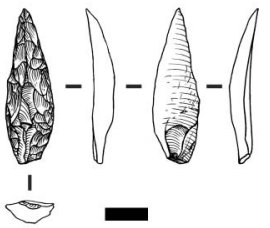

(a)

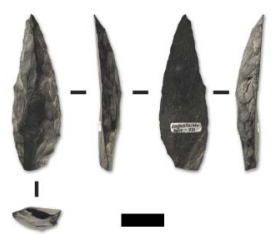

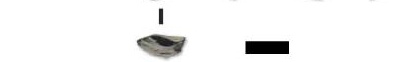
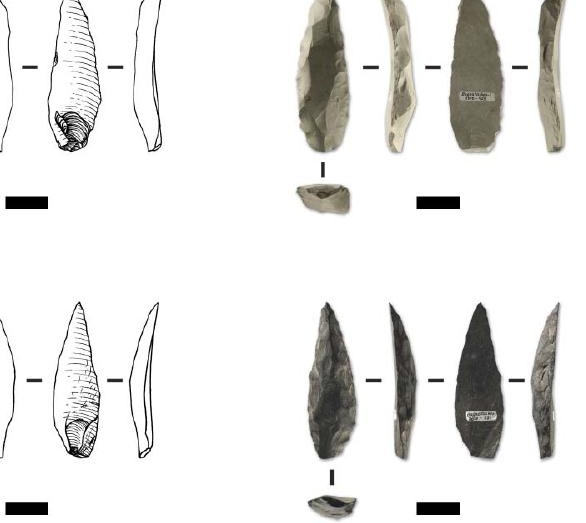


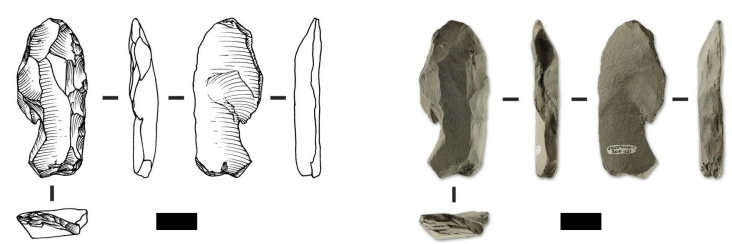

(b)
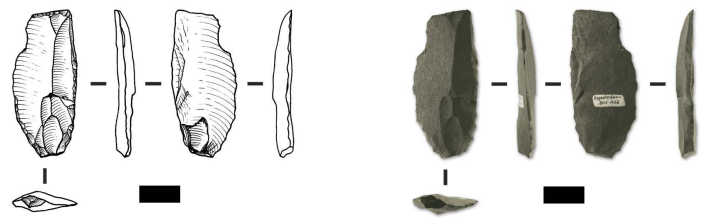

(c)
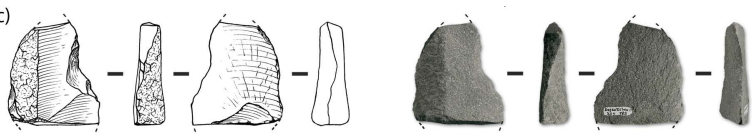

(d)
(e)
(e)
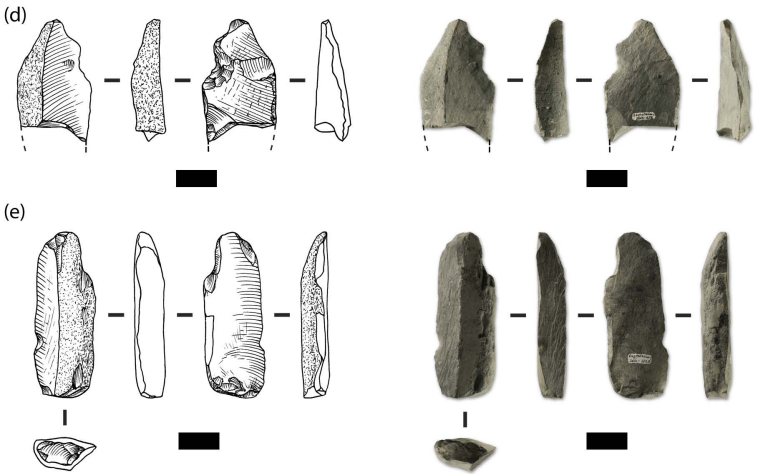


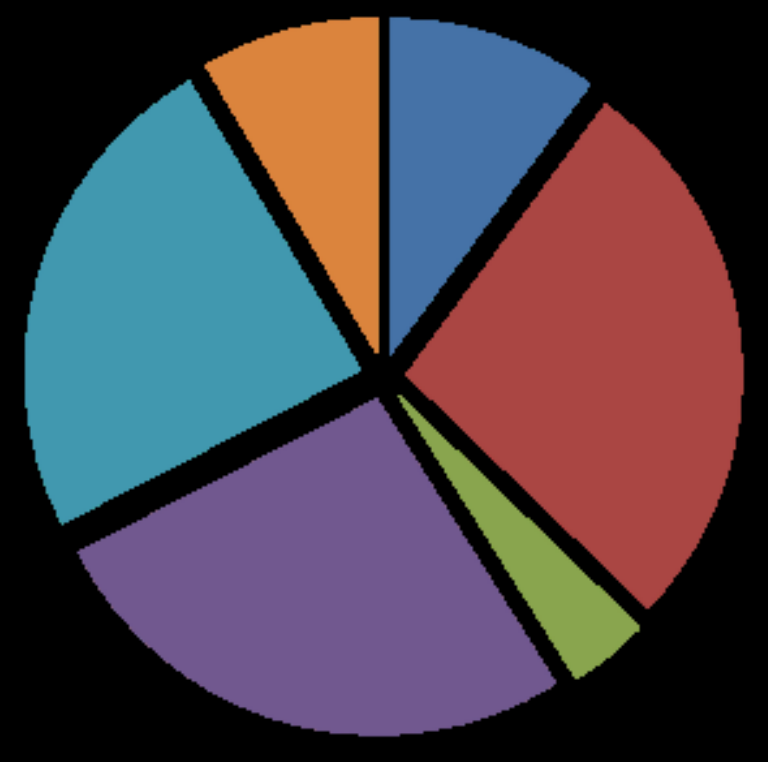

